\title{
Determinizmin Yeni Savunması: Nörobiyolojik İndirgemecilik
}

The New Defense of Determinism: Neurobiological Reduction

\section{Mehmet ÖDEMIŞ}

Dr., Millî Eğitim Bakanlığı, İzmir/Türkiye

PhD., The Ministry of National Education, İzmir/Turkey

mehmetodemis@hotmail.com | orcid.org/0000-0003-3657-480X | ror.org/00jga9g46

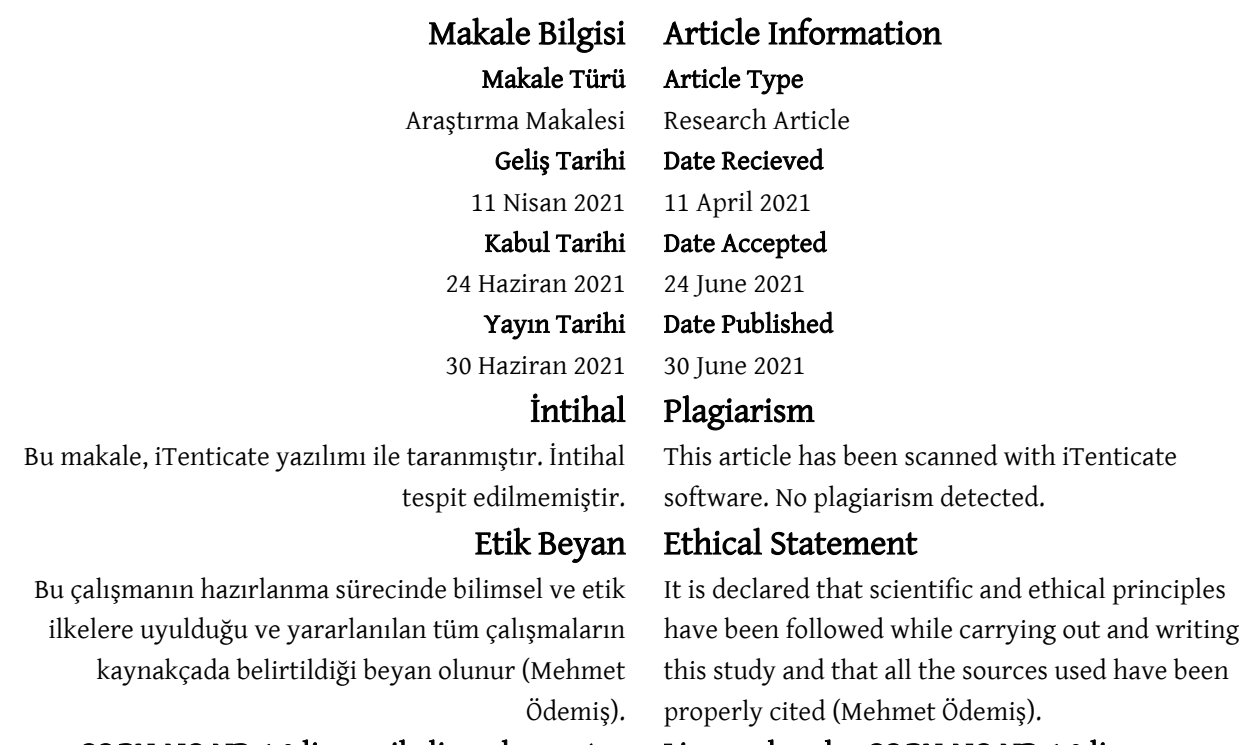

CC BY-NC-ND 4.0 lisansı ile lisanslanmıştır. Licensed under CC BY-NC-ND 4.0 license.

Atif | Cite As

c Ödemiş, Mehmet "Determinizmin Yeni Savunması: Nörobiyolojik İndirgemecilik". Kader 19/1 (Haziran 2021), 29-54. https://doi.org/10.18317/kaderdergi.913449 


\section{Öz}

Determinist düşünce tarih boyunca çeşitli kültür, inanç ve felsefede farklı veçheleriyle yer etmiş bir bakış açısı; hayatı, doğayı ve bir bütün olarak varlığı anlamlandırma biçimidir. Kültürel bir öğe olmaktan çıkıp sistematik bir kozmolojiye dönüşmesi, Yunan düşüncesiyle birlikte gerçekleşmiş̧ir. Önce Leucippos ardından Democritos ve Stoa okulu gibi ekoller, ontoloji ve kozmolojide determinist bir felsefeyi ispata girişmişlerdir.

İlerleyen zamanlarda fizik ve metafizik temelli belirlenimcilik yaklaşımları ortaya konmuş, genetikten davranışçllı̆̆a, kültürden psikolojiye, atomculuktan tanrıcıllğa varıncaya kadar geniş bir yelpaze teşekkül etmiştir. İster fizik isterse metafizik kaynaklı olsun bütün türleriyle belirlenimcilik, irade özgürlüğünü yok sayma; insanın davranışları üzerindeki faillik yetkinliğini reddetme iddiası içermektedir. Bu özelliği itibariyle etik kuramları, hukuk felsefeleri ve dinler açısından sakıncalı kabul edilmekte ve karşı çıkılmaktadır. Savlar, felsefi söylevlerden ve argümanlardan müteşekkil olduğunda rasyonaliteden neşet eden karşı söylevlerle çürütmek ya da en azından sarsmak imkân dahilinde iken bilimsel bulgulara dayandırıldığında sadece felsefi ve mantıkî delillerle itiraz kifayet etmemektedir.

$\mathrm{Bu}$ nedenle nörobiyolojik, nöropsikolojik, nöroteolojik vb. herhangi bir varsayımı yanıtlarken bilimsel bilginin epistemolojik değerini sorgulamak gerektiği kadar uygulanan deneyler ve klinik incelemelerin verilerini yöntem bilimsel açıdan kritik etmek de önemlidir. Diğer yandan -varsa- aynı konuyla ilgili yapılmış alternatif deneylere ulaşmak ya da Libet deneyi örneğinde olduğu gibi, bunların farklı şekillerde de yorumlanabileceğini ortaya koymak gerekmektedir. Zira klinik ya da deneysel araştırmalar; amaç, yöntem, kapsam ve incelenen konu bakımından bir çerçeve çizerek sonuç elde etmektedir. Verilerin nasıl yorumlanacă̆ı ise çoğu zaman araştırmacının hipotezine, ön kabullerine ya da dünya görüşüne bağlı olarak telif edilmektedir. Araştırmacının kişisel görüşünden bağımsız bir sonuç raporu, mümkün değildir. Nesnellik sorunu, bilimsel araştırmaların temel eksikliklerinden biri durumundadır.

Haddizatında günümüzde bilim, tarihte hiç olmadığı kadar bilgi üzerinde egemenlik sağlamış ve meşrulaştırıcı tek otorite sayılır hâle gelmiştir. Bilimin hayata getirdiği yenilik ve kolaylıklar, kitleler nazarında değerini ve önemini kutsamış ve tartışmasız kılmıştır. $O$ artık neredeyse her şeyi bilebilecek kudrettedir.

Biyolojik indirgemecilikten mantıksal dayanağını alan nörobiyolojik determinizm ise zihnin ontolojik farklılığa dayalı varlığını görmezden gelmenin, zihinle beyni eşitlemenin veya zihinselliği beynin en çok bir epifenomeni şeklinde tanımlamanın doğal sonucudur. Temel ayrışma materyalist felsefenin kabulünden kaynaklanmaktadır. Varlı̆̆ı sadece maddeye indirgeyen paradigmalar, tabiatıyla fizik ötesi olasılıkları hesaba dahil etmemektedir. Bu durumda her ne kadar qualia ya da öznel deneyim adı verilen problemler, çözülememiş bir şekilde orada öylece dursa da görmezden gelinerek iddia korunmaktadır. Entropi yasasının keşfi, Big Bang teorisi, kuantum fiziği gibi pek çok yeni gelişme materyalist felsefeyi sarsmış olmasına rağmen modern bilim, epistemolojik bir revizyona gitmeye direnmektedir. Oysa mevcut epistemoloji ile gerek evrenin gerekse varlığın bir bütün olarak kavranması mümkün görünmemektedir. Beyin üzerinde yapılan deneylerden yola çıarak insanın mahiyetini ve manevi tarafını anlamaya yönelik her teşebbüsün akim kalmasının en önemli nedeni budur.

Yirminci yüzyılın son çeyreğinden itibaren artan beyin araştırmaları, genler, nöronlar ve genel olarak beyin kimyasının insan davranışı üzerinde beklenenden daha fazla rol oynadığını ortaya koydu. Bu sonuçlar, bazı araştırmacılar tarafından özgür iradenin yanılsama olduğuna yönelik radikal bir iddia için araçsallaştırılırken diğer bazıları tarafından, iradenin eylemler üzerinde sanılandan daha az önemli kabul edilmesine yol açtı. Her iki düşüncede de irade özgürlüğünün göz ardı edildiği bir biyolojik determinizm modeli benimsenmişti. Yapılan çeşitli deneylerin tartışmalı yorumlarına dayanan hipotezler; dinî, ahlaki ve hukuki sorumlulukla ilgili kaygıların artmasına yol açtı. Her ne kadar sağduyu açısından insan, özgür olmayan bir varlık şeklinde düşünülemese de söz konusu bilimsel verilerin doğru bir yorumu bulunmadıkça gerçeğin üzerindeki sis perdesi kalkmayacaktı. İlk bakışta kuantum evreninde, evrensel determinizmi tartışmak makul görünmemekle birlikte bilinci de içerecek şekilde atom-üstü dünyada güçlü bir nedenselliğin hüküm sürdüğü iddiası hâlâ yerini korumaktadır. Bu nedenle öncelikle determinizmi kritize etmek ve ardından biyolojik determinizmi irdelemek kavramsal çerçeveyi belirlemeye yardımcı olacaktır. Bu makale genetik ve nörobiyolojinin, davranışın teşekkülündeki önemini kabul etmekle birlikte ahlaki failliği bütünüyle neden ortadan kaldıramayacağını açıklamayı amaçlamaktadır. Lakin insan beyni sofistike ve sırrı kolay kolay çözülemeyecek gibi görünen bir organdır. Hakkında elde edilen sınırlı bilgilerden yola çıkarak beynin dolayısıyla zihnin de deterministik evrenin bir parçası olduğunu iddia etmek için yeterli kanıt yoktur. Bilinç ve özgür irade gibi olguları; beynin fiziko-şimik yapısına, nöronların rastgele etkinliklerine ya da genetik bilgiden sağlanan avantajla girdileri otomatik bir şekilde çıktılara dönüştürme becerisine atfeden hipotezler, insan olmanın en yumuşak karnına; özgür iradeye saldırmaktadır. İşin ilginç ve paradoksal yanı; içinde bulunduğumuz çağda küresel medeniyet insana sonsuz özgürlük vaat ederken aynı çağın bilimi, özgür olmadığııı ispata çalışmaktadır.

Anahtar Kelimeler: Kelâm, İrade özgürlüğü, Determinizm, İndirgemecilik, Nörobiyoloji. 


\section{Abstract}

Determinist thought with its sui generis view on life, nature and being as a whole is a point of view that could be observed in many different cultures and beliefs. It was thanks to Greek thought that it ceased to be a cultural element and transformed into a systematic cosmology. Schools such as Leucippos, then Democritos and Stoa attempted to integrate the determinist philosophy into ontology and cosmology.

In the course of time, physics and metaphysics-based determinism approaches were introduced, and a wide spectrum has emerged from genetics to behaviorism, from culture to psychology, from atomism to divinity. Determinism, whether physical or metaphysical origin, ignores freedom of will and deny agency competence over human behavior. Due to this feature, it is opposed by ethical theories, legal philosophies and religions. When the arguments for determinism are possible to disprove logically and philosophically, this is not so easy when the claims base themselves on scientific base. As the logical consequence of this novel fact, it is important to question the epistemological value of scientific knowledge and critically analyze the data of experiments and clinical studies in terms of methodology when answering any hypothesis such as neuro-biological, neuro-psychological, or neuro-theological argumentations. On the other hand, it is necessary to reach alternative experiments on the same subject or to show that it is possible to interpret them in different ways, as in the example of the Libet experiment.

The neurobiological determinism based on biological reductionism, emerged as the result of ignoring the ontological difference of the mind, equating the mind with the brain, or defining mentality as an epiphenomenon of the brain. The main divergence stems from the acceptance of materialist philosophy. Paradigms that reduce existence only to matter do not take the metaphysical possibilities into account. In this case, although the problems called qualia or subjective experience stand there unresolved, the claim is preserved. Although many new developments such as the discovery of the entropy law, the big bang theory, and quantum physics have shaken the materialist philosophy, modern science resists an epistemological revision. However, with the current epistemology, it does not seem possible to grasp both the universe and the being as a whole. This is the most important reason why every attempt to understand the nature and spiritual side of human beings fails despite numerous experiments on the brain.

However, the human brain is an organ that seems sophisticated and its secrets cannot be easily solved. Since there is not enough information about the brain, there is not enough evidence to claim that the brain, and therefore the mind, are part of the deterministic universe.

Increasing brain researches since the last quarter of the twentieth century has revealed that genes, neurons and particularly brain chemistry claim much greater role than expected in human behavior. These results have been instrumentalized by some researchers for a radical claim that free will is an illusion, while by others it has led to the acceptance of will as less important over actions than was thought. Both ideas adopted a model of biological determinism in which freedom of will was ignored. Hypotheses based on controversial interpretations of various experiments raised concerns about religious, moral, and legal responsibility. Although man cannot be thought of as a non-free being from the point of view of common sense, the smog screen over the truth would not be lifted unless the scientific data in question had a correct interpretation. At first glance, it seems unreasonable to discuss universal determinism in the quantum universe. Nevertheless, the claim that strong causality prevails in the material world, including consciousness, remains in place. Therefore, firstly criticizing determinism and then examining biological determinism will help to fix the conceptual framework. This article aims to explain why genetics and neurobiology, while acknowledging their importance in the realization of behavior, can't completely abolish moral agency.

Some hypotheses attribute consciousness and free will to the physico-shimic structure of the brain, the random activity of neurons, or the ability to automatically transform inputs into outputs with the advantage of genetic information. This is the most sensitive and important point of being human; it attacks free will. Paradoxically, while global civilization of our time promises infinite freedom to human beings the science of the same age tries to prove that it is not free.

Keywords: Kalām, Freedom of will, Determinism, Reductionism, Neurobiology. 


\section{Giriş}

Determinist felsefe, özgür irade ve zorunsuzluğu reddederek varlık âlemindeki her olayın zorunlu sonuçlar doğuran bir sebeplilik zincirine bağlı olarak meydana geldiğini savunan teoridir. Zorunlu sonuçların doğmasına yol açan bu "sebep"ler, determinizmin türüne göre fiziksel ya da metafiziksel olabilmektedir. Özellikle katı belirlenimcilikte insan davranışları da bu sistemin dışında değildir. Bu nedenle özgür iradeye dayalı fiil icra etmek mevzu bahis değildir. Kısaca ifade etmek gerekirse determinizm (belirlenimcilik), bir şeyin diğer bir şeyle şartlandırılması demek olup hadiseler, onları doğuran etkenlerin doğal bir sonucudur. ${ }^{1}$ Determinizme göre iradi eylem sanılan hareketler; doğa olayları, sosyal ya da psikolojik etkenler gibi nedensel öncül konumundaki başka bazı amillerin rolüyle gerçekleşmektedir.

Düşünce tarihi boyunca serdedilmiş ve ortak noktaları; insanın ayırt edici özelliklerinden sayılan özgür iradenin yokluğunu savunan, bilim ve felsefe kökenli çeşitli teoriler geliştirilmiştir. Bunlar ana hatlarıyla şu şekilde sıralanabilir:²

1) Fiziksel determinizm: Bu teoride atomların maddi yapısı her şeyi belirleyen konumundadır. Doğa olayları, fiziksel olarak birbirinin sebep sonucu şeklinde cereyan eder.

2) Genetik determinizm: Bu yaklaşıma göre gen her şeyin belirleyicisidir. İnsan davranışları, irsiyet kaynaklı zorunluluklara göre şekillenir.

3) Nörofizyolojik determinizm: Buna göre beynin nörobiyolojik yapısı, bilinçli davranışlar da dahil olmak üzere tüm fiillerin kaynağını teşkil eder. Beyin, girdi çıktıları düzenleyen sofistike bir makine kabul edilir.

4) Davranışçı determinizm: Bu düşüncede davranışlar, dış dünyadaki uyaran-tepki nedenselliği çerçevesinde gerçekleşir. Davranışçllık açısından zihin durumları, belli davranışlara dönük yönelimleri ifade eder. Acı, sevinç ya da inanç gibi zihinsel davranışlardan bahsetmek aslında belirli davranışların potansiyel eğilim ve edimlerinden bahsetmektir.

5) Sosyolojik/kültürel determinizm: İnsanın davranışları, içine doğup büyüdüğü toplumun değer yargıları ve alışkanlıklarınca belirlenir. Kişiliğin tüm bileşenleri, çevresel etkilerle oluşturulur. Kültürden bağımsızlaşan ve onu aşabilen bir benlik hayal ürünüdür. Bahusus kitle iletişim çağında küresel kültür, tayin edicilikte yerel kültürlerin de önüne geçmiştir.

6) Teolojik/fatalist determinizm: İnsanlık tarihi kadar eski olan bu yaklaşım, ${ }^{3}$ kelâm tarihinde Cebriyye adıyla bilinir. Bu kabulde Tanrı'nın iradesi her şeyi belirler. Kelâm tarihindeki Cebriyye ile Yunan düşüncesinde izlerine rastladığımız fakat daha çok son dört yüz yıldır bilimin etkisiyle ön alan bir felsefe konumundaki determinizm arasındaki temel benzerlik, ikisinin de insandan özgür iradeyi ilga etmesidir. Aralarındaki fark ise Cebriyye'nin her şeyin faili olarak kâinatın mükevvini Allah Teâlâ'yı işaret etmesi, determinizmin ise tabiatı ve tabiatta içkin olan sebep-

Süleyman Hayri Bolay, Felsefi Doktrinler Sözlüğü (Ankara: Akçağ Yayınları, 1990), “Determinizm”, 46.

George Ellis, How Can Physics Underlie the Mind, Top-Dawn Causation in the Human Context (Heidelberg: Springer-Verlag, 2016), 375-376.

Determinist kabulün izlerine, İslâm'dan önceki Araplarda da rastlanır. Onlar, daha çok dehr (zaman) kavramı ve onun yıkıcılı̆̆ı üzerinden insanın etkinliğini yok sayan karamsar bir hayat algısı geliştirmişlerdi. Arap muhayyilesinde dehr, tanrısal olmayan, gayr-i şahsi mücerret bir güce karşıllk gelmekteydi. Bk. Toshihiko İzutsu, Kuran'da Allah ve İnsan, çev. Süleyman Ateş (İstanbul: Yeni Ufuklar Neşriyat, ts), 162-164; illhami Güler, Allah'in Ahlakiliği Sorunu (Ankara: Ankara Okulu Yayınları, 1998), 77. 
sonuç ilişkisinin yarattığı kuvveti fail kabul etmesidir. Cebriyye, Allah'ın kanunlarında bir değişiklik söz konusu olamayacağından yaratılmış her nesnenin onun irade ve kudret kanunları önünde boyun eğdiğini savunurken deterministler, doğa kanunlarının bir matematiği olduğunu ve meydana gelen her şeyin bu matematiğe bağıl bir şekilde cereyan ettiğini varsayarlar. ${ }^{4}$

\section{1. Özgür İrade-Belirlenimcilik İlişkisi Hakkında Geliştirilen Felsefi Nazariyeler}

İnsan iradesi ile ilgili tarihsel tartışma çoğu zaman özgür irade ve determinizm arasında dikotomik bir formda gelişmiştir. Bu kutbun bir ucunda insan, kendi düşüncelerini ve doğa tarafından serbest bırakılan davranışlarını seçerken diğer ucunda; seçim ve kendi kaderini tayin, aldatıcı bir histen ibaret sayılmış ve tüm insan eylemleri, doğa, biyoloji ve deneyimin rastgele birer ürünü şeklinde değerlendirilmiştir. ${ }^{5}$ Bu çerçevede determinizm ile özgür irade ilişkisi üzerine gerçekleşen tartışmalarda zamanla birbirinden oldukça farklı ya da ara bulucu işlevi gören çeşitli felsefi görüşler ortaya atılmıştır:

Fail nedenselliği: $\mathrm{Bu}$ yaklaşımda eylem, fiziksel olaylardan değil; öznenin seçimlerinden kaynaklanır.

Eliminativizm (Eleyicilik): Bu felsefe, insanların dillendirdiği inanç, arzu, irade vb. kavramların halk psikolojisinin bir ürünü olduğunu ve bilimsel bir değeri taşımadığını; bu nedenle de atılmaları gerektiğini savunur.

İndirgemecilik: Üst seviye kavramlar, alt düzey kavramlar yoluyla tam ve basit bir şekilde açıklanabilir. Örneğin zihin, beyin biyolojisinin bir ürünüdür ve fizyolojik bir temeli vardır. Haddizatında özgür seçim sanılan davranışlar da beyin mekanizması açısından fiziken açılanır niteliktedir.

Epifenomenalizm: Zihinsel durumlar, beynin fiziksel olaylarının birer epifenomeni (yan ürünü ya da üst görüngüsü) durumundadır. Epifenomenalizm, zihinsel olanla fiziksel olan arasında nedensel bağlantıların bulunduğunu ancak bunun fiziksel olandan zihinsel olana doğru tek yönlü olduğunu savunan felsefi görüștür. Bu teoride zihin; beyindeki faaliyetlerin bir çıktısı, ürünü mesabesindedir. Ontolojik açıdan zihnin beyne etki etme imkânı yoktur ve her zihinsel olayın bir elektro-kimyasal açıklaması vardır. Epifenomenalizm zihnin varlığını kabul etse de her şeyi maddi bir temele ve mekanik süreçlere indirgeyerek özgür iradeyi sakatlamaktadır.

Liberteryanizm (Özgürlükçülük): Bu yaklaşımda insan, doğanın bir parçası olsa da tabiat kanunlarının zorlayıcılığına maruz kalan bir varlık şeklinde değerlendirilmez. Evren hiçbir fiziksel durum tarafından belirlenmiş değildir, bu yüzden insan özgürdür. Evrende açıklanamayan türde olaylar mevcuttur ve insan özgür seçime dayalı davranışlarının müdrikidir. İnsanın seçimleri fizik

Ömer Nasuhi Bilmen, Muvazzah ìlm-i Kelâm (İstanbul: Ravza Yayınları, 1959), 233. Cebrî görüş her ne kadar Cehm b. Safvân'a isnad edilse de kaderciliği politik bir araç haline getiren Emeviler ile onların başta gelen muhaliflerinden olan Cehm'in düşüncelerinin paralellik arz etmesi kuşku vericidir. Cebriyye görüşünün Cehm'e ait olmayıp isnat edildiğine ilişkin tartışmalar için bk. Ahmet Erkol, “íslam Düşüncesinde Bir Okuma Örneği Olarak Cehm b. Safvan'ın Cebri Olduğu İddiasına Farklı Bir Yaklaşım”, Ekev Akademi Dergisi 7/17 (2003), 77-94.

William R. Miller - David J. Atencio, "Free Will as a Proportion of Variance", Are We Free? Psychology and Free Will, ed. John Baer vd. (New York: Oxford University Press, 2008), 275. 
yasalarına tabi değildir. İnsani eylemlerde iradenin işleyişinden başka bir nedensellikten bahsedilemez.

Uyumluluk (Bağdaşırcılık): Buna göre özgürlük determinizm ile uyumludur ve determinizm özgür iradeye engel değildir. Bu nedenle öznenin yüklem üzerindeki ahlaki ajanlı̆̆1 kalkmaz. Bağdaşırcılık determinizme daha yakın bir içerik kazandığında, yumuşak (soft) determinizm adını alır.

Uyumsuzluk: Özgürlüğün determinizm ile bağdaşmadığını iddia eder. Katı deterministler bu fikirdedir.

Determinizm: Evrenin bugünkü durumu, tamamen fiziksel yasaların ve evrenin başlangıç koşullarının bir çıktısıdır. Bu tasavvurda evren -Laplace'ın Cini örneğindeki gibi- bütünüyle mekaniktir.

Sert (katı) determinizm: Evren, fiziksel olaylar tarafından bütünüyle belirlenmiştir. Bu durumda insan da dahil hiçbir varlık için özgür iradeden söz etmek mümkün değildir. Determinizmin varlığına ilişkin kanıtların arttığı oranda bu konu hakkında düşünen insanlarda endişe artar zira bu durum; kontrol duygusunu ortadan kaldırır. Oysa insan, hayatının idaresinin kendinde olmasını ister. Kişisel öyküsünde olabildiği ölçüde obje değil, süje olmayı arzular.

\section{Dikotomik Ayrışma: Evrensel Determinizm ve Özgür İrade}

Milattan önce beşinci yüzyılda yaşayan Leucippos, "hiçbir şey rastgele gerçekleşmez ama her şey bir sebepten ve gereklilikten dolayı meydana gelir" fikrini serdettikten bir süre sonra Democritos, bu düşünceyi atomculukla birleştirmiş ve mekanik atomizm felsefesini kabul etmiştir. Buna göre ruhlar da dahil olmak üzere tüm maddeler sonsuz bir boşlukta hareket eden, yok edilemez, görünmez atomlardan meydana gelmekte ve her şey mekanik ilkelere göre hareket etmektedir. Bir tesadüf, şans ya da harici bir varlık tarafından verilmiş bir amaca sahip değillerdir.

Bununla birlikte Democritos, ruhun hareketlerinin düşünce ve eylemlerin düzenlenmesinde kısmi bir etkisinin olduğunu kabul ederek bir teselli verdi. Epicuros (MÖ 341-270) Democritos'un sade metafiziğine şerh düşerek katı bir determinizme karşı insan seçimi için güvenli bir alan açmaya çalıştı. Atomların dönebileceğini, böylece doğumla birlikte atomlarımızın kesinleşmiş konfigürasyonu yerine karakterimiz aracıllğıyla hareketlerimizi kontrol edebileceğimizi savundu. Buna karşın Stoacı filozoflar tam bir determinizmi savunanlar arasında yer aldı. Onlar istisnasız hiçbir şeyin sebepsiz olarak kozmosun içinde var olmayacağını ileri sürüyordu. ${ }^{6}$

Leucippos'un "her olayın sebep sonuç zincirine bağlı olarak gerçekleştiği" iddiasına ilk tepki, Platon ve Aristo'dan gelmişti. Onlar, insanın öznelliğini ve özgürlüğünü ortadan kaldıran bu fikre önce ihtirazda sonra da itirazda bulunmaktan geri kalmamışlardı. Daha sonraki çağlarda, insanı davranışlarından sorumlu tutacak kadar bir özgür iradeye sahip olduğu düşüncesi kabul görerek yaygınlık kazandı. Bu açıklama, semavi dinlerdeki insan konseptine de mutabıktı. Böylelikle hem insanın edimlerinde hem de evren özelinde meydana gelecek kötülüklerden Tanrı yekten sorumlu tutulmayacaktı. Bu düşüncenin hakimiyeti Isaac Newton'ın (1643-1727) 1687 yılında Philosophia

Bernard Berofsky, Nature's Challenge to Free Will (New York: Oxford University Press, 2012), 7; Karl Popper - John J. Eccles, The Self and Its Brain - An Argument for Interactionism (New York: Springer International, 1983), 32. 
Naturalis Principia Mathematica adlı muhallet eserini yayınlayıncaya kadar sürdü. Çünkü onun mekanik evren tasavvuru, kuantum fiziğiyle ilgili ilk teoriler ortaya atılıncaya kadar bilim dünyasına egemen oldu. Evrenin mekanikliği fikri henüz tam olarak yerleşmeden canlıların da birer makine olduğu teorisi, Descartes tarafından ileri sürüldü. Onun bu görüşü, çağdaşlarının dikkatini çekmiş ve makine hayvanlar yaklaşımı biyolojide yeni bir sayfanın açılmasını sağlamıştı. İlerleyen süreçte makine hayvan kavramsallaştırması "makine insan"a (the human machine)

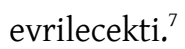

Kuantum fiziği ise indeterminizmi sadece fiziğe değil, felsefeye yeniden davet edecek; atom altı parçacıkların hareketinin, kuantum sıçramalarından radyoaktif dalgalanmaya kadar geniş bir alanın öngörülemezliğini tescilleyecekti. Kuantum evren bilim insanlarına istatistik toplamaktan daha fazlasını bahşetmiyordu.

XX. asra kadar Isaac Newton, James C. Maxwell (1831-1879) ve Albert Einstein'in (1879-1955) madde ve enerjinin uzay ve zamandaki işleyişine dair teorileri iki önemli özellik barındırıyordu: Determinizm ve nedensellik. Klasik fiziğin kendine has özelliklerinden hareketle ileri sürülen bazı sert yorumlar özgür iradeye alan açmıyordu. 1920'lerden itibaren kuantum mekaniği belirmeye başladı ve bu yeni fizik, dünyanın sanıldığının aksine deterministik olmadığını savundu. Yeni fizik, geçmişteki pozitif yasaların bugünün sonuçlarını kesin olarak belirlemediğini belirterek olasılıklar dünyasında meydana gelebilecek alternatifler için açık bir spektrum teklif etti. Kuantum mekaniğinin özgür irade için bir açıklama olabileceğini ilk ortaya atansa Arthur Eddington (1882-1944) oldu. Ancak bu nazariye, sinir bilimciler ve pek çok filozof tarafindan kabul görmedi. Her şeyin kuark düzeyinde "rastgele" hareket ettiği bir evrende özgür iradeden nasıl bahsedilebilirdi. Bu rastgelelik, kimi bilim insanlarına göre özgür irade üzerindeki insani kontrolü de ortadan kaldırıyordu. ${ }^{8}$ Yine de kuantum mekaniğinin başka özellikleri -ölçüm ve gözlem sürecindeki değiş̧enler- üzerinden kimi bilim insanları, kuantum fiziği ve bilinç arasında yakın bir bağlantı olduğunu öne sürmeye devam etti.

Determinizmde, nedensellik evrenin temel ve zorunlu kaidesidir. Varlık adına cereyan eden bütün devinimler, evrensel bir nedensellik yasasıyla birbirine bağlıdır. Olaylar arasındaki nedensellik bağı (illiyet) makroskobik evrenin kanunlarında açıkça müşahede edilebilir. İki hidrojenle bir oksijenin bir araya her gelişinde suyu meydana getirmesi, evreni öngörülebilir yapar. $\mathrm{Bu}$ öngörülebilirlik ise bilim yapmanın temel ussal ilkesini teşkil eder. Aynı nedenlerin aynı sonucu doğurması için uygun koşulların oluşması gerekir. Bu yüzden nedenle sonuç arasındaki ilişki, tek yönlü bir ilişkiden ziyade bir karşllıklılık ilişkisidir. ${ }^{9}$

Determinizm, varlığını şu analoji ile ispat etmeye çalışır: $:^{10}$

- Şurası açıktır ki evrendeki tüm olgular tabiat kanunlarına istinat eden bir sebeplilik zincirine bağlı olarak meydana gelir. Tüm canlı ve cansız varlıklar için geçerli olan bu süreçten, insanın müstağni kalması için neden yoktur.

Bk. Juliean Ofray De La Mattrie, L'Homme Machine, çev. Ehra Bayramoğlu (İstanbul: Havass Yayınları, 1980).

David Hodgson, The Oxford Handbook of Free Will, ed. Robert Kane (New York: Oxford University Press, 2002), 57-58.

M. Niyazi Öktem, Özgürlük Sorunu ve Hukuk (İstanbul: İ̈ Hukuk Fakültesi Yayınları, 1977), 251-252.

Bilmen, Muvazzah ílm-i Kelâm, 230-231. 
- Bugün artık bilinmektedir ki insanlardan sudur eden pek çok eylem, aynı şekilde çeşitli sebeplerin sonucu olarak gelişmektedir.

- İnsan zihninde, herhangi bir işi yapıp yapmama konusunda tereddüt ederken sebeplerden biri galip gelir ve seçeneklerden birine yönelir. Tereddüt esnasında şılardan birinin baskın çıkmasının nedeni, insanın iradi tavrı değil; o şıkkı tercih etmesine yol açan sebeplerin yarattığı zorunluluktur.

- İnsan, dışsal etkenler dışında arzu ve güdü gibi çeşitli baskın eğilimlerin etkisiyle de davranış ortaya koyan bir varlıktır. Bu da bir tür zorunluluk hâli oluşturmaktadır.

Mantıkçı deterministler, geçmiş kadar geleceğin de değiştirilemez olduğunu iddia ederler. 0 zaten kaderin kitabında yazılmıştır. Gelecek ise geçmişin döl yatağında şekillenmiştir. Bunun için ileri sürdükleri delillerden biri, gerçeğin zamansızlığına dair atıftır. Kehanetler değişmez ve mutlaktır çünkü mantıksal olarak zorunludur. Gelecekteki hadiseler, şu anda tabi oldukları faktörlere bağlıdırlar ve bu yüzden zihnin müteakip değişim olasıllğını da failin kontrolüyle ilgili herhangi bir faktör olasılığını da hariçte tutarlar. ${ }^{11}$

Her olayın bir takım yakın veya uzak sebeplere bağlı olarak ortaya çıktığını daha sonra ortaya çıkan bu yeni hadisenin başka birtakım olayların sebebine dönüştüğünü ve bütün olup bitenlerin "kozal bir açıklaması"nın yapılabileceğini kabul etme prensibine dayanan determinizm, kozmosla sürekli ve dinamik bir bağ kuran Tanrı tasavvurunu sakatladığı gibi insani fiilleri de kapsama dahil ederek özgürlük nosyonunu baltalar. Tam da bu yönüyle fatalizm ile determinizm birbirinden ayrılır çünkü bir fatalist ortaya çıkan olgularda kendi iradesinin hiçbir şekilde etkisinin olmadığını kabul etmektedir. Oysa determinizmde, insanın fiilleri birtakım sebeplerin sonucu olarak ortaya çıksa da fiilin kendisi başka hareketlerin sebebi olabilmektedir.

Tartışma; determinizmin görünür âlemdeki varlığının kabulünden çok bunun insan davranışlarına teşmilinden kaynaklanmaktadır. Katı deterministler insanın, yaptığından başkasını yapma seçeneğinin bulunmadığını savunurlar. "Başka türlü de yapabilirdim" veya "başka bir seçenek de söz konusu olabilirdi" ihtimali, bu felsefede mevzubahis değildir. Ilımlı determinizme göre ise insan, her hâlükârda çeşitli saiklere bağlı olarak hareket eder lakin bu bağıllık, irade hürriyetini ortadan kaldırmaz. Katı determinizm yanlıştır çünkü o, fiillerin ortaya çıkmasını sağlayan beşerî karakteri, yani fiillerin zuhurunda etkili olan psikolojik, fizyolojik yasaları tümüyle reddetmektedir. İnsanın muktedir olması eylemin gerçekleşmesinde tek başına bireysel iradenin belirleyici olduğu anlamına gelmese de fiilin gerçekleşme sürecini bütünüyle kuşatan bir zorlamadan bahsetmek mümkün değildir. Fakat katı deterministler, eylemin icrasında "iç zorlama"nın etkisinin dikkate alınması gerektiğini savunurlar. Fiillerin arka planında insan arzu ve istekleri ile bir bütün olarak karakter yatar. Aynı zamanda biyolojik kalıtım ve çevresel etkinin varlığı, inkâr edilemeyecek kadar etkileyici hatta belirleyici olabilmektedir. Onlar, eylemin gerçekleşmesinde bütün bu unsurların etkisini hesaba katmadan tam bir özgür iradeden bahsetmenin imkansızlığına dikkat çekerler. ${ }^{12}$ Katı belirlenimciliği benimseyen bazı bilimciler, bu varsayımın açık bir gerçek olduğunu ileri sürerler.

John Randolph Lucas, The Freedom of the Will (Oxford: Clarendon Press, 1970), 65-66.

Mehmet S. Aydın, Din Felsefesi (İzmir: İlahiyat Fakültesi Vakfı Yayınları, 1999), 162-163. 
Bununla birlikte bu kimseler, kendi öznel yaşamlarında hangi saiklerle karar verdiklerini açılamakta zorlanırlar. İnsanoğlunun övgüye ve yergiye mazhar olan davranışlarının arkasında yatan süreci anlamlandırmanın zorluğunun farkındadırlar. Tehdit altındaki ahlaki tutarlılığı ve ileri sürülen nihilizmi bağdaştırmanın bir yolu mümkün görünmemektedir.

Determinist felsefeye göre aslında olanlardan başka hiçbir şey mümkün değildi. Çünkü evvelde her şey belirlenmişti. Özetle nedensel süreçler, sonucu kaçınılmaz hâle getirecek şekilde devinim hâlindedir. Bireyin çoklu olasılıklara olan inancı, bu süreçlerin nasıl sonuçlanacağı konusundaki cehaletinin bir sonucudur. Filmin sonunu, geleceği ya da akıbeti bilmemek, insanda kendi seçimleri üzerinde bir söz hakkı bulunduğu sanrısını yaratır. Deterministlerin çoğunun inandığ şey, tam olarak böyledir. ${ }^{13}$ Buna karşıllk özgür irade doktrini, gerçekten çok sayıda olasılık olduğunu ve hangisinin gerçekleşeceğine otonom bir iradeyle karar verildiğini savunur. Psikologların çoğu özgür irade konusunda mütereddittir; zira onlara göre iradenin varllğını kabul etmek, kişinin davranışının; buna neden olabilecek önceki tüm olaylara tamamen bağışıklık kazandığını da kabul etmek demektir. Diğer yandan bilişsel bilim üzerine düşünenlerin çoğu, fiziksel nedensellik yasalarının tüm davranışları açıklamada yeterli olduğuna inanmaktadır. Şayet fiziksel nedensellik her şeyi açklarsa niyet, asla herhangi bir şekilde davranışa neden olamamaktadır.

İnsanın eylemlerinin kozalite kanunlarına bağlı olup olmadığı hakkında gerekircilik (neccesity) ile belirlenimcilik (determinism) terimleri arasında dikkat gerektiren nüanslar bulunmaktadır. Zamansal ardışıklık ile ardışık zorunluluk mefhumları üzerinde yeni bakış açılarına ve son bilgiler ışı̆̆ında yeniden düşünmeye gereksinim vardır. Kuşkusuz kavramların yanlış kullanımı ya da ahlaki faillikle ilgili endişeler konuyu objektif ve sarih bir şekilde tartışmayı zorlaştırmaktadır. Gerçekten özgür iradenin metafizik teorileriyle bilimsel kanıtlar arasında bir uyum mümkün müdür? İnsanın fiil işleme melekesinin çeşitli psikolojik ve biyolojik saikler tarafından yönlendirilmesi, onun ahlaki fail (moral agent) özelliğini ortadan kaldırır mı? Özgür irade ile psikolojik ve biyolojik unsurların birleştirilmesi ya da özgür iradenin saikleri yönetmesi olasılıktan bütünüyle uzak mıdır? Benliğin ya da ruhun kendisinin fiilin nedeni olması ihtimal dış1 mıdır? Belki de nedensellik ve zorunluluk sözcükleri doğru mefhumlar değildir. ${ }^{14}$ Eylemlerin belirli etkilere açık oluşu hatta bu etkilerin fiilin başlangıcının nedeni oluşu, sürecin kendiliğ̈indenliğinin kanıtı sayılamayacağı gibi iradenin yokluğunu da ispatlamayacaktır. Gerekliliklerin lüzumu, iradenin ilzamına kâfi değildir.

\footnotetext{
Baumeister, The Cultural Animal, 299-300.

John Stuart Mill, A System of Logic Ratiocinative and İnductive (Books IV-VI), ed. J.M. Robson (USA: Harper \& Brothers, 1981), 8/836-843. Mill, fizik âlemdeki neden-sonuç ilişkisinin olduğu gibi insana da teşmil edilmesine itiraz eder. İnsan dışsal dünyadan etkilenir fakat bütünüyle dışındaki dünya tarafından belirlenmez. Onun seçimlerinde kendi iradesi de rol oynar. Bu anlamda insan sadece başka faktörler tarafından inşa edilen bir nesne değil, kendi kendini inşa eden özel bir varlıktır. Deterministlerin dışsal etmenler adını verdiği unsurların ne kadar dışsal yani çevresel ve kalıtımsal olduğu tartışmalıdır. Verilen kararlarda insana özgü içsel süreçler de etkindir. Mill, fizik âlemin terminolojisi ile insanı tarif ve kategorize etmenin yanlışlığına dikkat çeker. Bilimsel ilerlemenin herhangi bir döneminde üretilen ve muhtemelen gelecekte değişecek olan mekanik kuramlarla insanı tanımlamaya çalışmak usûlî bir hatadır. Doğa yasaları adını verdiğimiz yasalar, bugüne kadar elde ettiğimiz bilgilerle vardığımız yorumlardan ibarettir. Oysa bilimsel bilginin tarihi, tam bir istikrarsıllık ve değişkenliği gözler önüne serer. Bk. Funda Neslioğlu, “İrade Özgürlüğü Sorununun Çözümsüzlüğü Üzerine”, Felsefe Dünyası 47 (2008/1), 179-184.
} 
Şayet sebeplilik zincirinden muaf bir fiil mümkün değilse özgür iradenin bizatihi kendisi eylemsellikte yeter sebep şeklinde telakki edilebilir. İnsanın ihtiyârı, doğadaki sebeplilik zincirinin bir halkası olabilir. Haddizatında insani irade, evrendeki matematiksel denkleme bir sürpriz etkisi yapabilir. Zira iradî fiil, neticesi öngörülemeyendir. İnsan davranışlarının etkilere açık bir şekilde meydana geldiği hatta bu etkilerin çeşitliliğinden dolayı zaman zaman tereddütte kalındığı doğrudur. Bu etkilerden birinin insanın cüz’i iradesi üzerinde daha dominant oluşuyla fiilin teşekkül etmesi, hürriyeti ilga etmez. Arzu, şehvet, açlık, susuzluk gibi güdüler, insanı her zaman davranışa itmez. Bunların insan iradesiyle kontrol altına alınabildiği ve yönetilebilen güdüler olduğu tecrübeyle sabittir. ${ }^{15}$

Katı determinizmi doğru kabul etmek, özgür iradeyi ve sorumluluğu yok saymak demektir. $\mathrm{Bu}$ yaklaşımda ne katile kızmak ne de maktule üzülmek mümkündür. Katil kendi seçimleri dışında bir şey yapmıştır ki ahlaken ve hukuken mesul tutulamaz. Maktul ise zaten başına gelecek bir şeyi yaşamıştır ki bunun için üzülmek yersizdir. Öte yandan ahlaki ve hukuki sorumluluktan bahsedebilmek için determinizmi tümüyle reddetmeye gerek yoktur. Evet, insan filleri bir sebeplilik zinciri içerisinde ve belli ölçülerde determine olarak gerçekleşir. ${ }^{16}$ Kritik olan bu sebepliliğin bir icbar yaratıp yaratmadığıdır. Kişinin irade ve kudreti, bu kozal akış içerisinde rüzgârın önündeki yaprak gibi değildir. Akışı değiștirebilir hatta durdurabilir yahut ona yön verebilir.

"Mekanistlerin yaptığı gibi determinizmi nedensellik yasalarının zorunluluğuna bağlayıp özgürlüğü yadsımak, cansız maddenin atomlarıyla insan atomlarını özdeşleştirmeye çalışmak; cansız evrenin yasalarıyla organik, psikolojik evrenin yasalarını aynı mekanik yasalara indirgemek, bilimsel ve felsefi çalışma yetersizliğinden başka bir şey değildir." ${ }^{17}$ Tüm nedenlerin faktörel gücünü aynı odağa yerleștirerek kalıtım, biyo-fizyoloji ve psikolojik amilleri aynileştirmek, bir tür materyalizmdir.

Bazı aşırı deterministler "şayet ayaklarınız yere basıyorsa bu sizin değil, içinde yaşadığınız gezegenin kararıdır” diyerek kozmik yasalarla bilinçli eylemleri indirgemede radikalleşir. Bu varsayımda özgürlüğün gerçek bir özgürlük olabilmesi için her türlü sebep-sonuç ilişkisinden yalıtılmış olması zorunludur. O kadar ki karar, içsel ve dışsal her türlü nedenin yönlendirmesinden ve etkisinden arınmış bir ortamda verilmelidir. ${ }^{18}$ Oysa ileri sürüldüğü gibi doğanın bir parçası olan insanın kendini kuşatan doğa yasalarından bütünüyle bağımsızlaşması mümkün değildir. İnsanı özgür kılan, ussal yetenekleriyle bu etkenleri, yönetebilmesi hatta gerektiğinde aşabilmesi ya da aksi durumda içlerinden birini tercih edebilmesidir.

Bilim felsefesi bugün, özgür istenç ile belirleyicilik kuramı arasında bocalamaktadır. ${ }^{19}$ Oysa felsefe ile bilim rakip değildir. Bilim dünyaya bakmaya ve onu tanımlamaya dair bir teklif sunarken felsefenin çabası onu anlamlandırmak ve kozmostaki yerini kavramaktır. Bilimin muhkem muteberliğine dayanarak zaman zaman felsefeyi tahfif etme teşebbüsüne rağmen kabul

Bilmen, Muvazzah ilm-i Kelâm, 231-233.

Aydın, Din Felsefesi, 164.

Öktem, Özgürlük Sorunu ve Hukuk, 253.

Daniel C. Dennett, Özgürlüğün Evrimi, çev. Çağatay Tarhan (İstanbul: Alfa Yayıncılık, 2016), 126.

Roger Penrose, Kralın Yeni Aklı-Bilgisayar, Zekâ ve Fizik Yasaları, çev. Tekin Dereli (İstanbul: Koç Üniversitesi Yayınları, 2017), 440. 
edilmelidir ki felsefe, bilimden daha az değerli değildir. Çünkü J. Dewey'in sözleriyle felsefe "gerçeklikten ziyade anlamla meşguldür." Bilime taptığımız ve felsefeden korktuğumuz, onun sorgulamalarını içi boş ve değersiz kabul ettiğimiz sürece insanlığın büyük bir bilime sahip olması ve malumatı yerli yerine koyarak bütüncül bir okuma yapması zor görünmektedir. Çünkü felsefe gerçeklere dayanan fakat onlar tarafından belirlenmeyen bir olasılıklar vizyonudur. 0 , değerleri birbiriyle ilişkilendirirken "spekülatif bir cüret" kullanır. ${ }^{20}$

Geçmişte psikologların ve davranış bilimcilerin, bugünse sinir bilimcilerin insan davranışının nasıl ortaya çıktığını göstermedeki her yeni başarısı; ilk bakışta özgür irade fikri için başka bir yenilgi gibi görünmektedir. Aslında, bilimsel girişimlerin çoğu, nedensel ilkelerin ve nedensel kalıpların bulunduğu varsayımına dayanmaktadır. Kozalite, bilim yapabilmenin ussal zeminidir. Oysa çoğu sosyal bilimcinin liberal inancının bir parçası olmasının ötesinde, yapılan yeni araştırmalar, insanların kalıtımlarından çok çevrelerinin bir ürünü olduğunu ve bu nedenle çevreyi değiştirmenin davranışları değiştirmenin etkili bir yolu olduğunu göstermektedir. Öte yandan her sonucu determinizm çerçevesinde yorumlamak kolaya kaçmaktır ve objektif bir bilim insanı determinizm hakkında şüpheci olmalıdır. Evrensel nedensellik doğru fakat determinizm yanlış olabilir. Zira katı determinizm; kanıtlanamayan bir varsayımdır, deneysel bir bulgu değildir. ${ }^{21}$ Haddizatında özgür iradeyi reddeden hipotez, özgür iradeyle ilgili tecrübe edilen gerçek ve derin deneyimler yoluyla kolaylıkla çürütülebilir. ${ }^{22}$

Bilincin ve özgür iradenin bir yanılsama olabileceği fikri, bilinçli seçimlerin dünya ve ahiret hayatını belirlediğine inananlar için radikal bir şekilde rahatsı edicidir. Bir kişinin bilinçli iradesinin doğru olanı seçme ve yanlış olanı reddetmedeki rolü, onu teolojik bir mesele hâline getirir ve insan davranışlarının mekanik açıklamaları hakkındaki kaygılar, sadece dinler açısından değil; Batı da dahil tüm kültürler nazarında toplumbilimciler tarafından paylaşılır.

\section{Determinizm ve Özgürlüğün Nörobiyolojisi}

Nörobiyolojik determinizmin, nörobiyoloji henüz bir alt disiplin olarak gelişmeden hatta biyoloji, 19. yüzyılda henüz bir bilim hâline gelmeden çok önce ortaya çıtığı ileri sürülür. Buna göre İncil'de yer alanlar da dahil olmak üzere insanın ortaya çıkışı ve gelişimi hakkındaki bilimsel olmayan açıklamalarda, biyolojik determinist düşüncenin ilk izleri sürülebilir. Hz. Nuh'un oğullarından Ham ve sonrasında gözlemlenen çeşitli hadiselerin anlatımında bu düşünceye rastlandığı iddia edilir. ${ }^{23}$ Bugünkü çoğu bilim anlayışına göre biyolojik determinizmin bu en eski biçimleri, doğaüstü bir tasarıma dayanmaktaydı. Tufan sonrası Hz. Nuh'un oğullarına dayanan ırkların çeşitliliği sadece fizyolojik ve biyolojik çeşitliliği değil, karakteristik ayrımları da içeriyordu. ${ }^{24}$

20 Sidney Hook, The Quest for Being and Other Studies in Naturalism and Humanism (London: Macmillan, 1961), 227-228.

${ }_{21}$ Peter von Inwagen, “The Incompatibility of Responsability And Determinism”, Action and Responsibility, ed. Michael Bradie-Myles Brand (Ohio: Bowling Green State University, 1980), 30-37; Roy F. Baumeister, The Cultural Animal: Human Nature, Meaning, and Social Life (New York: Oxford University Press, 2005), 300.

22 Michele Caponigro, "Free Will from Outside Spacetime? The Role of Observer in Quantum Mechanics", NeuroQuantology 16/8 (2018), 16-21.

$23 \quad$ Kutsal Kitap ve Deuterokanonik Kitaplar (İstanbul: Kitabı Mukaddes Şirketi, 2015), Yar.9:19-20, 10:2-32.

24 Joseph L. Graves Jr., "Great Is Their Sin: Biological Determinism in the Age of Genomics", Annals of AAPSS 661 (September 2015), 24-50. 
Bugün tartıştığımız biyolojik determinizmin temeli ise 1900'lerde Gregor Mendel (1822-1884) tarafından keşfedilen ve insan farklılıklarının biyolojik temeli olarak kabul edilen genetik bilimine dayanır. Genetik hakkında artan bilgiler öncelikle Fransa'da Alfred Binet (1857-1911) tarafından kurulan ardından Amerika Birleşik Devletleri'ne ithal edilen ve Lewis M. Terman (1877-1956) tarafından popüler hâle getirilen zekâ testleri üzerinden bir belirlenimci nosyona dönüşmüştür. Kalıtımsal zekânın tek belirleyici unsur olarak düşünülmesi, 1916 yılında Stanford-Binet testi aracılığıyla Amerika Birleşik Devletleri'nde zihinsel test hareketini başlattı. Zekânın nicel olarak ölçülebileceği fikri ve Mendel genetiğindeki hızlı gelişmeler, biyolojik determinizmin güçlü ve popüler bir varyantını doğurdu. Öjenik hareket kısa sürede pek çok ülkede yayıldı. Toplumun sağlık ve refahının daha zeki insanlara bağlı olduğu, zekânın esasında genler tarafından belirlendiği fakat daha az zeki olanların çok fazla çocuk ürettiği için nüfusun kontrol altına alınması gerektiği, bu amaçla hukuki düzenlemeler yapılarak durumun tersine çevrilmesinin önemi savunuldu. Öjeni doktrinine göre siyahların, Doğuluların, Güney ve Doğu Avrupalıların genetik olarak zihinsel ve ahlaki açıdan aşağı olduğu iddia edildi. ${ }^{25}$ Öyle ki bu ırkçı yaklaşım 1924 tarihli ABD Göçmenlik Yasasını ortaya çıardı. ${ }^{26}$

Diğer yandan Alman ırkçıllğının ürettiği şok, dünyanın büyük bir savaş ve yıkımla yüzleşmesine yol açtı. Biyolojik determinizm, çok uzak olmayan meşum sonuçlarına rağmen bugün hâlâ kimi entelektüel çevrelerde daha sofistike ve bilimsel (!) formlarda devam etmektedir. En son sürümlerden birine göre okul çağındaki çocuklar arasında gözlemlenen başarı farklılıkları, esas olarak sosyoekonomik nedenlerden ziyade genetik farklılıklardan kaynaklanmaktadır ve bu nedenle değiştirilemez niteliktedir. Diğer yandan ırklar arasındaki ortalama okul başarısı ve sosyoekonomik seviyelerdeki farklıllklar da (genellikle siyah ve beyaz) çoğunlukla genetiktir ve bu nedenle bunların da değiștirilmesi pek mümkün değildir. ${ }^{27}$

Sosyal sınıflar arasındaki farklılıklar ve toplumsal statü, çoğunlukla genetik ve zekâdaki değişmez farklılıkların sonucuysa bireysel çabaları aşan daha genel deterministik bir dünya düzeninden söz etmek kaçınılmazdır. ${ }^{28}$ illaveten erkek ve kadın cinsi arasındaki statü ve rol farklılıkları da büyük ölçüde biyolojik, evrimsel transmutasyonun doğal bir sonucu ve değişmez kabul edilir. ${ }^{29}$ Irkçllik ve şovenizme bilimsel bir temel bulmak için yapılan çalışmaların, bazı entelektüeller arasında hâlâ geçerliliğini koruduğu gözlemlenebilmektedir.

Determinizmin bu türünde biyolojik etik sistemleri iki farklı düşünce çizgisini içerir: Öncelikle davranışlarımız biyolojik olarak belirlenmektedir. Ahlak ve inançsa hayatta kalma yolunda (homeostasis) bir katma değer ifade ettiği ve toplum hayatının düzeninde yararlı bir işlev gördüğü için evrim tarafından geliştirilmiştir. Toplumsal değer yargıları genlerde saklanır ve iradi fiiller de dahil eylemlerin temel amacı, genetik materyali korumaktır. ${ }^{30}$ Oysa insan benliğinin

25 Fred W. Johnson - Arthur R. Jensen, "Race and Sex Differences in Head Size and IQ", Intelligence 18, (1994), 309-333.

26 Mezkûr yasa, Asya kökenlilerin Amerika’ya göçüne sınırlamalar içermekteydi.

27 Arthur R. Jensen, "Intelligence, Learning Ability and Socioeconomic Status", The Journal of Special Education 3/23 (1969), 23-35; Jensen, "How Much Can We Boost IQ and Scholastic Achievement”, Harvard Educational Review 39/1, (1969), 1-123.

28 Richard Herrnstein, "I.Q.", The Atlantic 228 (1971), 43-64.

29 Bk. Lionel Tiger - Robin Fox, The İmperial Man (New York: Routledge, 1971); Lionel Tiger - Robin Fox, "The Zoological Perspective in Social Science", Man 1/1 (1966), 75-81

30 Rosemary Rodd, “The Challenge of Biological Determinism", Philosophy 62/239 (1987), 84-93. 
teşekkülünde, kalıtım ve çevrenin dahli olduğunu kabul etmek başka, sadece kalıtım ve çevrenin ürünü olan kompozit bir materyal şeklinde tanımlanması başkadır. Bir seçim yapıldığında bunu kim yapar? Kalıtım, çevre ya da üniversal determinizmin bileşenleri mi yoksa bütün bunların ve daha fazlasının içinde hatta üstünde tekil ve öznel olarak insan dediğimiz varlık mı?

İki özdeş, tek yumurta ikizi insanı hayal edelim! Akla gelebilecek her şekilde (genler, önceki deneyimler, mevcut beyin durumları vs.) birbirlerinin mükemmel klonları bireyler olsunlar. Onlara "kahve mi, çay mı?" şeklinde basit bir soru sorsak mutlak şekilde aynı cevabı vereceklerini düşünebilir miyiz? Bu sorunun cevabının bilinme oranı ile özdeş deneklerin olası cevaplarını bilmenin oranı aynıdır. William James'in dediği gibi "gerçek iki taraftan biriyle birlikte olduğunda aynı anda diğerini yanlış yapar.” Bazı belirsizliklerin epistemolojik ve içsel olarak tahmin edilemezliği özgürlüğün kanıtıdır. Kuantum parçacıklar düzeyinde olduğu gibi, insan davranışları bazen içsel öngörülemezlik sergileyecektir. Bu durumda insanlar, en azından mütevazı ölçüde, özgür faillerdir; yani cüz’̂̂/kısmi/sınırlı bir irade özgürlüğünü hak ederler. Böylece onlar, kendi eylemlerinin nisbî ilk nedeni olurlar. Akla gelebilecek her biyolojik, psikolojik ve sosyal etki hesaba katılsa da kahveye veya çaya; ahlaki veya ahlaki olmayan eylemlere yönelmenin öngörülemezliği ve özgürlüğü korunur. ${ }^{31}$ Genler ve yetişme koşullarına bağlı beyin durumları belirli davranış eğilimlerini belirleyebilir fakat nihayetinde sorumluluk alan ve karar veren biyolojik yapının fevkinde bir benlik vardır.

Sosyobiyolojik yaklaşımda ise insan, davranışlarının olası genetik etkilerinin farkında olmayarak hareket eder. İç gözlem yoluyla elde edilen bu kanıt, beyin süreçlerinin diline çevrildiğinde gerçekleşen olay şu şekilde izah edilir: ${ }^{32}$

a) Evrim, insan beynini gelecek nesillere gen transferini aktarmayı sağlayacak şekilde programlamıştır. Beynin belirli şartlardaki hesaplamaları buna koşullanmıştır. Beyin mekanizması, davranışları kontrol ederken olasılık hesaplamalarını bu amaca göre planlar. Diğer bireylerle iletişime geçerken söz konusu mekanizma tarafindan yapılan hesaplamalar sırasında ortaya çıkan beyin durumları, minimax kuralına göre işlev kazanır. Yerine göre şefkat, acıma, yerine göre öfke, nefret, korku vb. hislerin tezahürü bu hesaplamalar sonucu varlık kazanır.

b) Peki duygular bile beyin mekanizmasının genetik koşullanmasının doğal sonucu olarak yaşanıyorsa bilinç ne işe yaramaktadır? Bu durumda bilinç, beynin otomatik kompozisyonunun sonuçlarını değiştiremese de koşulları anlamlandıran ve değer veren sınırlı bir fonksiyon ifa etmektedir. Ortaya çıkan fenomenler yalnızca beyin durumlarının bir yönü olduğu için burada bir tür çaresiz “makinedeki hayalet”ten söz etmek mümkün değildir. Beynimiz genlerle değil, beyin durumlarıyla ilgili minimum hesaplamalar yapacak şekilde programlandığından ve farklı bireylere verilen ağırlık, genetik ilişkinin katı hesaplamasına değil; olasılık faktörlerine bağlı olduğundan özgürlükle ilgili kaygıları esnetmek pekâlâ mümkündür. Teoriye göre diğerkâmlık gibi insansı özellikler ve hayata değer atfetme deneyimi, genetik mirasımızın bir parçasıdır. Tıpkı hayatta kalmak için yeri geldiğinde herkesin bencilleşebileceği gibi. Nörobilimin ortaya koyduğu ve özgür iradenin mekanikliği ya da yokluğuyla ilişkilendirilen bilgiler, insanın değerden

\footnotetext{
31 David G. Myers, "Determined and Free”, Are We Free? Psychology and Free Will, ed. John Baer vd. (New York: Oxford University Press, 2008), 32.

32 Rodd, "The Challenge of Biological Determinism", 84-93.
} 
soyunması/uzaklaşması veya onu göz ardı etmesi anlamına gelmeyecektir. Ahlaki akıl yürütme ve davranış için öznel argümantasyon yaratma hâlâ imkân dahilindedir. Beyin, gerekçeli argümanları girdi olarak kabul edebilir ve bunların davranışa dönüşüp dönüşmeyeceğini ya da eylemin mahiyetini hesaplayabilir.

Davranışımızın genetik olarak şekillendirilmiş bir beynin fizyolojik aktivitesinden kaynaklandığı fikri, geleneksel özgür irade görüşünü çürütür. Bu durum davranışımızı, hareket hâlindeki moleküllerin otomatik bir sonucu hâline getirir ve nedensiz bir davranış seçicisine (nefs, ego, benlik, ruh vb.) yer bırakmaz. Eğer davranışlarımız, beynin rastgele aktivitelerinden ibaretse seçim yapmak için ıstırap çekmemize ya da düşünsel kuluçkaya yatmamıza gerek yok demektir. Ancak bilinçli karar vermekten vazgeçilmiş bir hayat fikrini tahayyül etmek bile bir "Valium" (yüksek doz müsekkin) işlevi görebilir. Oysa seçme deneyimi, bir kurgu değildir. ${ }^{33}$ Davranış, seçimi esnasında sinirsel ve sinir üstü etkin bir fonksiyon gerektiren gerçek bir süreçtir.

Beynin hangi bölgesinin hangi işlevi gördüğünü bilmek, hangi nöronların hangi bilişsel becerilerde ateşlendiğini keşfetmek ve hangi uyaranın beynin hangi bileșenlerinden geçerek davranışa dönüştüğünü görüntülemek hatta duyguları biyolojik moleküllerden ibaret kabul etmek; niyetlilik, öznellik, irade, vicdan, hayal vb. zihinsel durumları anlamak için yeterli değildir. Refleksif ve reflektif davranışlar arasında düşünce süreçlerinin gayr-i maddi yapısından kaynaklı temel bir fark vardır.

Modern bilim anlayışı, tüm detayları matematiksel olarak hesaplanabilir ve bu bilinebilirlik nedeniyle hükmedilebilir bir evren tasavvuruna sahiptir. İnsan da bu devasa sistemin alelade cüzlerinden biri kabul edilir. Bu paradigmada henüz bütünüyle keşfedilememiş olsa da insan beyni, evreni yöneten külli yasalardan bağımsız değildir. Var olan her şey fizikseldir ve fiziksel yasalara göre hareket eder. Beyin için de girdiler ve çıktıların nedenselliğinden başka bir açıklama söz konusu değildir. Bugün pek çok bilim insanı, zihni üreten insan beynini genel yasalara dahil ederek hesaplanabilirlik ve öngörülebilirliği sağlamak istese de varsayımda hep bir şeylerin eksik kaldığına dair o rahatsız edici duygudan kurtulamamaktadır. Diğer yandan hesaplanabilirliğin matematiksel kesinlikle aynı şey olmadığını da hatırlatmak gerekir. Mutlak Platoncu matematiksel evrende tahmin edildiğinden daha fazla gizem vardır. ${ }^{34}$ İnsan beyni de sirrına vakıf olmak için galaksiler kadar uzak ve erişilemez olmamasına rağmen bu gizemlerin başında gelmektedir.

Genetik ve sinir bilim alanında ortaya çıkan zengin ve yeni veriler, determinizm ile özgür irade arasında kalan ahlaki faillik meselesi hakkındaki gerçekliğin, muhtemelen uyumluluk (compatibilism) fikrine yakın bir yerde yattığını gösteriyor. Uyumluluk ya da bağdaşırcılık, deterministik evren fikriyle özgür iradenin birlikte imkanını varsayar. İnsan özgürlüğünün varlığı ve yokluğu ile sınırlarını tayin eden tek sistemin biyolojik sistem olduğu kabul edilse bile beyin fizyolojisinin, standart kalıplar üzerinden herkesi tekleştirdiği söylenemez. İnsan genomu, tüm vücudun yapısını en ince ayrıntısına kadar tasarlar ve genetik bilgi tüm hücrelere nüfuz eder. Fakat beyin devrelerinin tamamı, genler tarafından belirlendiği şekilde benlik ve kimliğin

\footnotetext{
33 Steven Pinker, “The Fear of Determinism”, Are We Free? Psychology and Free Will, ed. John Baer vd. (New York: Oxford University Press, 2008), 311.

34 Penrose, Kralın Yeni Akl, 455.
} 
oluşmasında yegâne unsur değildir. ${ }^{35}$ Adeta parmak izi ya da ses rengi gibi her bireyin beyin yapısı özel ve özneldir.

1) Öncelikle öznel deneyim hiçbir insanda tıpatıp aynı olmadığından beynin nöral yolakları ve zihinsel durumlar, kişiye özgüdür.

2) İkinci olarak kültür başta olmak üzere epigenetik faktörlerin her beyinde bırakacağı izler de farklı olacaktır. Epigenetik, beyin yapısı ve işlevi ile çevre ve geçmiş deneyimlerin karar verme süreçlerinde etkileşime girerek rol oynadığı tezidir. Buna göre insan, kendi kararlarını vermek için sınırlı fakat mükellefiyet için yeterli özgür iradeye sahiptir. Bu nedenle eylemlerinden ahlaken sorumludur.

3) Bilinçli ve daha çok bilinçdışı öğrenme kabiliyetinin nörobiyolojik temelini oluşturan ayna nöronların keşfi tür olarak kültürel etkilenime, çevresel belirlenime ve ayna benlik yapısına ne kadar açık olduğumuzu kanıtlamıştır. Fakat aynı zamanda benliğin dinamik yapısını da gözler önüne sermiştir.

4) Beynin plastisite denilen esnek yapısı, yaşamsal deneyimlere bağlı olarak değişir ve gelişir. İnsani etkinlikler, dış dünya ile etkileşim ve eğitim sürecinde edindiklerinin tesiri ile modellenmiş beyin; bireysel tarihi ve yörüngeyi tayin eder. Bu irtibat, beynin işleyişi ile dış dünyanın reel olgusu ve onun kişisel kavranışı arasında özdeşliğe yakın bir yapı inşa eder. Çevresel etki, epigenetik yontma, nöroplasitisitenin çamursu tasarımı sahnededir. Tam bu nokta, belirlilikle belirlenimci olmamanın şaşırtııı bir şekilde yollarının kesiştiği özgürlük alanıdır. ${ }^{36}$

"İnsanlar hayvandır ve yaptığımız her şey biyolojik potansiyelimizde yatar." ${ }^{37}$ diyen evrimsel biyolog Stephen Jay Gould (1941-2002) insanların hayvan olduğu ifadesinin, spesifik davranış kalıplarımızın ve sosyal düzenlemelerin herhangi bir şekilde doğrudan genlerimiz tarafından belirlendiği anlamına gelmediğinin altını çizerek biyolojik determinizme şerh düşer.

Beynin, yaşam boyu hem hormonlar hem de deneyimler tarafından organize ve aktive edilen son derece plastik, modüler olarak dimorfik (çift kutuplu), gelişimsel olarak öğrenmeye açık bir organ olduğunu kabul etmek "iyi bilim”"in temelidir. Öğrenmenin ve hafızanın altında yatan moleküler, hücresel ve sistemsel nöroplastisite; yaşanan deneyimlerle benzersiz ve özgün bir şekilde beyni sürekli şekillendirir. Tercihler, reflekse ya da otomatizme dayalı davranışsal seçimlerle karıştırılmaması gereken motivasyonel tutkulardır. Özgürlük, bir tercihle karşı karşıya kalındığında "evet ya da hayır" demekten çok daha fazla bir kabiliyettir: 0 , beynin plastikiyeti göz önüne alındığında bir "olma vetiresi"dir. Kendimizi şekillendirme ve yaratma tecrübesidir. Nietzsche'nin deyimiyle "Gerçekten neysek o olma becerisidir." ${ }^{38}$ Fakat gerçekte ne olduğumuz kalıplaşmış, hazır ve belirli bir "şey” değildir.

Karar verme süreçlerinde muhtemel bir durumda nöronlar ateşlenir, benlik beyin aracılığıyla şartları değerlendirerek "en doğru" şıkkı/davranışı, görünen bir fenomen olarak eşlik eden uygun

\footnotetext{
35 Antonio R. Damasio, Descartes'in Yanilgısı-Duygu, Akıl ve İnsan Beyni, çev. Bahar Atlamaz (İstanbul: Varlık Yayınları, 1999), 258.

36 Catherine Malabou, Beynimizle Ne Yapmaliyız, çev. Selim Karlıtekin (ìstanbul: Küre Yayınları, 2010), 50.

37 Stephen Jay Gould, Ever Since Darwin, Reflections in Natural History (New York: W. W. Norton \& Company Ltd., 2007), 252.

38 Rollo May, Kendini Arayan İnsan, çev. Ayşen Karpat (İstanbul: Kuraldışı Yayıncılık, 1997), 154.
} 
duyguyla birlikte hesaplar ve ardından gerekli kas hücrelerini aktive eder. Bu süreç her zaman sıkı bir şekilde genetik olarak kontrol edilemez çünkü insanlar dahil birçok hayvan davranışlarını deneyime uygun olarak değiştirme konusunda hatırı sayılır bir yeteneğe sahiptir. Bu tür bir değişiklik, temelde yatan genetik kısıtlamalara (bedeni yöneten konumundaki beynin büyüklüğü ve gücü, olası temel dürtüler gibi) bağlı olacaktır. Diğer yandan hayatta kalma temel dürtüsü bencilliği öne çıkarsa da bilinç düzeyinde sevgi, korku, hırs, güven, nefret, merhamet vb. duygular tarafından motive edildiğimizi hissederiz.

Kuşkusuz insanın kendisinin karar veremediği ve doğuştan gelen özellikleri vardır. Örneğin erkekler, sahip oldukları Y kromozomu nedeniyle doğum yapamazlar. Ten rengi, cinsiyet, milliyet, çeşitli fenotip özellikleri gibi durumlar kalıtımsaldır. İrade, eğitim ya da kültür üzerinden yürütülecek herhangi bir çalışma, bu nitelikleri değiştirmeyecektir. Her insanın gen havuzunda birden fazla ırka ait genotiplere rastlamak mümkünse de genelde ağırlı̆̆ bir ırkın DNA'sı teşkil eder. Fakat bu özellikler dışında kalan nerdeyse her durum, özgür irade yoluyla ya da epigenetik etkenlerle değişime açıktır. Şayet bir genetik belirlenimden söz edeceksek bu sadece yukarıda saydığımız doğuştan gelen özellikler için mümkündür.

Bazı araştırmacılara göre sinir bilim beynin işleyişi açısından bir mekanizm önerebilir fakat asla determinizm öneremez. ${ }^{39}$ Nörobilimin bulguları deterministik bir evrende yaşadığımızı ve beynin de bu evrenin bir parçası olarak bütünüyle deterministik bir işleyişe sahip olduğunu göstermez. Determinizm kabul edilse dahi Werner Heisenberg'in (1901-1976) "belirsizlik ilkesi" temel moleküler faaliyetler hakkında tam olarak bilgi sahibi olmamızı engeller. Sinir bilim bu konuda bir tespitte bulunmak yerine belirsiz veya olasılıklarla (stochastic) dolu süreçlerin iç içe geçtiği bir mekanizma sunacaktır. Doğada geçerli determinizm, özgür irade söz konusu olduğunda geçerli değildir. En azından bunun için bir kanıt bulunmamakta sadece spekülasyon yapılmaktadır. Zira "Fiziksel olayların kategorisi ile öznel olayların kategorisi arasında açıklanamayan bir boşluk vardır."

Zihinsel ya da fiziksel bir eylemin startını verecek olan bir nöronun ateşlenip ateşlenmeyeceği, hangi aksiyon potansiyellerini ürettiği veya kaç tane sinaptik vezikül salındığını öngörmek mümkün değildir. Muhtemel en iyi model; olasılıklara dayalı fenomenlerden ibarettir. ${ }^{41}$ Aynı zamanda mezkûr öngörülemezliğin gerçekten temelde belirsiz süreçlerden mi yoksa mevcut epistemolojik imkânlarımızın ötesinde kalan karmaşık deterministik süreçlerden mi kaynaklandığı da sinir bilimin sessiz kalacağı hususlardandır.

Paradoksal olan şu ki determinizmin -fizik âlemde gerilemesine rağmen- insan davranışları konusunda ilginç bir şekilde gücünü artırdığı düşünülmektedir. Bu mütenakız eğilimlerin birkaç

39 Libet'in karar verme süreçleri ile ilgili ünlü deneyinin beynin mekanik bir şekilde işlediğini gösterdiğini dolayısıyla determinizmi haklı çıkardığını savunanların hem Libet'in değerlendirmelerini hem de bu çıarımın sadece olasılıklardan biri olduğunu göz önünde bulundurması ve deneyle ilgili metodik eleştirileri dikkate almadan karar vermemesi gerekir. Bk. Adina L. Roskies, “Why Libet's Studies Don't Pose a Threat to Free Will In Conscious Will and Responsibility", Conscious Will and Responsibility: A Tribute to Benjamin Libet (Oxford Series in Neuroscience, Law and Philosophy), ed. W. Sinnott-Armstrong - L. Nadel (New York: Oxford University Press, 2011), 11-22.

40 Benjamin Libet, "Do We Have Free Will?", Journal of Consciousness Studies 6 (1999), 47-57.

${ }_{41}$ Adina Roskies, "Neuroscientific Challenges to Free Will and Responsibility", TRENDS in Cognitive Sciences 10/9 (2006), 419-423. 
sebebi vardır: "Birincisi, fizik dışındaki bilimlerdeki (biyoloji, davranışsal ve sosyal bilimler) son gelişmeler birçok kişiyi, davranışlarımızın çoğunun bizim tarafımızdan bilinmeyen nedenlerle belirlendiğine ve geçmişin insanları, sanıldığından daha fazla kontrol ettiğine ikna etmiştir." Bununla genetik, beyin ve davranış ilişkisi üzerine yapılan biyokimyasal araştırmalar, psikanaliz ve bilişsel bilimlerdeki çeşitli yeni bulgular, yapay zekâ, hayvan ve insan davranışları arasındaki karşılaştırmalı klinik incelemelerin sonuçları, psikolojik şartlanma ve davranış değişikliği teorileri, dil, kültür ve insan yetiştirme (eğitim-öğretim) yöntemlerinin etkilerine dair kanitlar kast edilmektedir. İkinci bir nedense "Kuantum fiziğindeki belirsizliğin, insan davranışları mevzubahis edildiğinde geçerli olmadığı teorisidir. Kuantum belirsizlik, temel parçacıklar için önemli olmakla birlikte insan beyni gibi daha büyük fiziksel sistemlerde geçerli değildir.” $\mathrm{Bu}$ nedenle "insan tercihlerini ve eylemlerini tüm pratik amaçlar için belirlenmiş olarak görmeye devam edebiliriz" iddiası korunur. Çünkü beyindeki kuantum sıçramaları veya sinir sistemi gibi belirlenemeyen kuantum olaylarının, eyleme ya da düşünceye, beklenmedik bir şekilde ortaya çıkmak gibi tahmin ve kontrol edilemez bir boyut kattığı düşünülür. Her ikisi de kendi alanlarında Nobel sahibi olan fizikçi Arthur Holly Compton (1892-1962) ve nörofizyolog Sir John Eccles'in (1903-1997) savunmalarına rağmen kuantum teorisinin özgür iradenin açıklanmasında bir değer taşımadığı ileri sürülür. Eğer beyindeki olaylar, kuantum sıçramalarla kendiliğinden ve kontrolsüzce meydana geliyorsa bu durumun; failin özerkliğini ve özgürlüğünü artırmaktan çok, olayı epilepsi gibi problemli bir forma sokabileceği kaydedilir. ${ }^{42}$

Bu sınıf düşünürler, kuantum belirsizliğin sadece mikro dünyada geçerli olduğunu fakat atomüstü dünyada böyle bir belirsizlikten bahsetmenin mümkün olmadığını savunur. Bu yüzden maddi dünyada determinizmden ödün vermemek gerekir. Bu yaklaşıma göre parçacıklar düzeyindeki indeterminizm önemsizdir çünkü insan bedenleri de dahil nesneler düzeyinde belirsizlikten eser yoktur. Her şey nedenselliğin mantığına uygun bir şekilde cereyan eder. Bu tezi öne sürenler "büyük sayılar kanunu" (the law of large numbers) adı verilen genel bir postulata atıfta bulunur. Fizikteki temel açıklayıcı mekanizmalar aşağıdan yukarıya çalıştı̆̆ı için nedensellik yasası tüm fenomenlere uygulanır. Bu durumda her şeyin bilardo toplarının hareketindeki gibi işlediği iddia edilir. Bu açılamaya, cansız bir ceset için bu benzetmenin mümkün olduğu ancak bilinçli insan davranışlarının bilardo toplarının hareket etme biçimiyle eşleştirilmesinin yanlışlığı nedeniyle itiraz edilebilir. Çünkü insan bilinçliliği sayesinde kendi kendisini belirler. Davranışları harici nedenlerin basit tepkimelerinden ibaret değildir. Beyindeki milyonlarca hücrenin belirsizliği, insanın farkında olduğu yüksek seviyedeki özgürlüğü üretmek için tesadüfen bir araya gelmez. Bu sadece bize beyindeki parçacıkların kuantum belirsizlik sayesinde, basit nedensellikten ari kaldığ bilgisini verir. ${ }^{43}$ Belirsizliği belirli hâle getiren bilinçli iradenin dokunuşudur ki bu, bizi eylemlerimiz karşısında sorumlu yapar. Belki de özgür irade meselesindeki asıl sorun, belirlenimcilikle hem bağdaşan hem bağdaşmayan bir yapıya sahip olmasıdır. Çünkü külli bir rastlantısallığın insanı özgür kılmayacağı açıktır. ${ }^{44}$

42 Robert Kane, The Significance of Free Will (New York: Oxford University Press, 1998), 9-10.

43 David Ray Griffin, Religion and Scientific Naturalism, Overcoming to Conflicts (New York: State University of New York Press, 2000), 154-155.

${ }_{44}$ Ned Block, Bilinç Üzerine Konuşmalar, haz. Susan Blackmore, çev. Seda Akbıyık (İstanbul: Küre Yayınları, 2017), 45. 
Öte yandan beynin, tesadüfi ya da indeterminist olaylara maruz kalan atom-altı parçacıklardan müteşekkil olması durumunda birinin tam olarak ne düşüneceğini ya da nasıl davranacağını belirlemek imkânsızlaşacaktır. Şu hâlde determinizmin iddiasının çürüdüğü iddia edilebilir. Bu, bazı araştırmacılara göre kısmen doğru bir ifadedir. Zira bugün evrenin gerçekten belirsiz olduğu artık anlaşılmıştır. Ancak evrenin indeterminist bir karakterde olması da bizi, eylemlerimizin oluşmasında şans ya da rastlantı faktörünün belirleyici olması gibi bir durumla yüzleşmek zorunda bırakabilir. Bu nedenle bazı düşünürler, determinist ya da indeterminist evrenler içerisinde hangisinin özgür iradeye daha çok imkân verdiği sorusuna; determinist evren cevabını verirler. Zira determinist evrende, insanın davranışlarının nedeni çoğu zaman kendi geçmiş seçimleridir. Bu düşünceye göre en azından geleceği belirleyen geçmişte, kişinin kendi imzasının bulunduğu savlanır. ${ }^{45}$ Oysa kişi bugünkü eylemlerini özgür bir şekilde ifa edemiyorsa geçmiş eylemleri için bunu iddia etmek nasıl mümkün olacaktır?

Açıkçası, birçok insan hareketi bilinçli özgür irade dışında ortaya çıkar. Bahusus hasarlı beyinlerle insanlar körlük gösterebilir. (Bilinçli olarak göremediklerini görüyormuş gibi davranabilirler.) Muayyen bölünmüş bir beyinde bir kişi, sağ yarım kürede ortaya çıan nesneleri tanıdığı hâlde korpus kallosum bağı koptuğu için sol yarımkürede onu ifade edemeyebilir. Sanki bedeninde, bilinçli benlik için müsait olmayan örtük hatıralar ve bir başka benlik var gibi davranabilir. Şu hâlde "Özgürlük nerededir?" sorusunun cevabı; eylemleri determine edilse bile insanın, alternatifler arasından bilinçli seçim yapmakta özgür olduğudur. ${ }^{46}$ Kararlarımızın önemli olduğunu ve felsefi sebepler olmasa da pratikte toplumun, vicdanın ya da Tanrı'nın bizi sorumlu tutabileceğini biliriz. Determinizmin inkâr ettiği șey, içsel inançlarımızın ve seçimlerimizin pratik sonuçları değil fakat nihayetinde insanların kendi belirleyicileri olduğu fail nedensellik fikridir.

Öte yandan yapılan çeşitli deneylerde elde edilen kanıtlar, insanların özgürlükçü sezgilere sahip olduklarını göstermektedir. Çocuklardan yetişkinlere kadar her yaştan insan eylemsel failliğin sezgisel olarak farkındadır. Çoğu kişi bir fiili icra ettiğinde aksini de yapabileceğinin idrakindedir. Aynı şekilde evrenin determinist mi yoksa indeterminist mi olduğuna yönelik soruya verilen cevaplarda insanların \%90-95’i evrenin belirsizliğini, iradenin varlığı nedeniyle hürriyetin reel sezgisini ve eylemlerindeki ahlaki sorumluluğu bilirler. ${ }^{47}$ Peki, şayet evren deterministik ve bilinçli davranışlar dahi bundan müstağni değilse insana özgür olduğunu düşündüren nedir? Deterministik evren bunu neden determine etmemektedir? Varsayıldığ gibi evrendeki belirlenimci gerçeğe rağmen özgür olduğumuzu sezgisel olarak biliyor ve fiilen fark ediyorsak bu sezgi ve farkındalığın kaynağı nedir? Açıkçası bu durumu, evrimsel homeostasis ${ }^{48}$ ile izah etmek tatminkâr bulunmayacaktır.

Nörobiyoloji, nöropsikoloji ve nöroteoloji başta olmak üzere nörobilim araştırmalarının sağlayacağı en önemli katkı; davranışları gerçekte neyin harekete geçirdiği ve hedeflere ulaşmanın önündeki ayartıcılar hakkında bir anlayış kazandırmak olacaktır. Böylece ödül ve

45 Miller - Atencio, "Free Will as a Proportion of Variance”, 305-306.

46 Myers, "Determined and Free", 36-40.

$47 \quad$ Bk. Shaun Nichols, "The Folk Psychology of Free Will: Fits and Starts", Mind and Language 19, (2004), 473-502; Nichols, "Folk İntuitions on Free Will”, Journal of Cognition and Culture 6 (2006), 57-86.

48 Fizyoloji biliminde, organizmanın hayatta kalmak için çevre şartlarına uyum sağlayacak şekilde kendini düzenleme süreçleri için kullanılan bir terimdir. 
motivasyon sisteminin çalışma tarzı ve onu manipüle eden faktörler ile insani ilişkilerimiz, potansiyellerimiz ve uğruna çaba sarf ettiğimiz mutluluk gibi hayatın en kişisel yönleri üzerinde hem bireyler hem de toplum olarak sağlıklı bir kontrol sağlayabiliriz. ${ }^{49}$

Deterministlerin, bilinçli davranışları beyindeki sinir hücrelerinin (nöronların) belirli ve sıkı nedensellik süreçlerine indirgemeleri doğru değildir zira şuur hâlleri, beyindeki hücre hareketliliğinden daha fazlasını ifade eder. Bu yüzden beyindeki fizik ya da fiziko-şimik olaylarla açıklanamazlar. Bilinçli farkındalığın beyne bağlı olduğu bir gerçektir fakat beynin, bilinçliliği tüm tafsilatıyla resmettiği ya da şuurun beynin fiziksel bir parçası olduğu söylenemez. Bilinçlilik beyin sayesinde tezahür eder, onunla var olur lakin beyin tarafından determine edilemez. ${ }^{50}$

Diğer yandan beynin fiziksel olarak belirlenmişliği üzerinden davranışların da belirlendiği iddiasının, özgürlük realitesini yok edemese de düşüncelerimizde daha başka zararlı tortular bırakması muhtemeldir. Özgürlüğün bir yanılsamadan ibaret olduğu ve eylemlerin ise buna bağlı olarak kendiliğinden gerçekleştiği savı, insandaki ahlaki sorumluluğu sarsacak ve onu hukuk, etik ve din gibi normatif kurumlar karşısında daha serbest/serkeş hâle getirebilecektir. Aynı tehlike determinizmden daha sofistike bir şekilde irade özgürlüğünü baltalama potansiyeline sahip olan indirgemecilik içinde geçerlidir. Zihni beyinle özdeşleştiren, özgür iradeyi rastgele ya da önceki beyin durumları tarafından belirlenmiş nöron ateşlemelerine, duyguları beyin kimyasına indirgeyen bir yaklaşım, irade özgürlüğü karşısında determinizmden daha yıpratıcı niteliktedir.

Bu durumda kişi, birinin bacağını bile isteye kırdığında, ahlaken kendiliğinden düşen bir taştan daha fazla sorumlu olmayacaktır. Ayrıca zihinsel özellikleri maddi beyin durumlarına atfederek bilinçli deneyimleri beyin süreçlerinin nörobiyolojik kimyasına atfetmek o kadar kolay değildir. Örneğin genel anestezi sırasında beynin uyutulduğu ve buna bağlı olarak bilinçli deneyimin güvenli bir şekilde durdurulduğu düşünülür. Oysa bir araştırmacı, anestezi uygulanmış bir hayvanın gözünün içine ışık tuttuğunda hâlâ birincil görsel kortekste piramidal nöronlardan ateşlenmiş potansiyelleri kaydeder. ${ }^{51}$ Genel anestezi altında ameliyat edilmekte olan bir hastada dahi bir tür bilincin var olduğu denemelerle saptanmıştır. ${ }^{52} \mathrm{Bu}$ da bilincin bütünüyle ortadan kalkmadığını ve gerçekten beyin kimyasına bağlı olup olmadığını tartışmalı hâle getirir.

Özgürlüğün bir saat gibi işleyen evrenin çarklarının arasında mümkün olmadığını savunan determinist görüş; ahlak ve erdem, iyilik ve kötülük gibi nosyonları yok etmektedir. "Belirlenimcilik kâbusu" özgür iradeyi yok sayarken beraberinde daha temel pek çok şeyi de imha ettiğini çoğu zaman umursamaz. Bu paradigmada bütün, parçalarından ibarettir ve bütünü anlamak için parçayı anlamak yeterlidir. Zihni meydana getiren beyin olduğuna göre beynin mikroskobik düzeydeki çalışma prensiplerini çözümlemek bütün olarak beyni ve böylece zihni de anlamak demektir. Zira mezkûr iddia zihni, mekanik bir alet olan beynin çıktısından ibaret sayar. ${ }^{53}$

49 Dan Ariely, The Upside of Irrationality: The Unexpected Benefits of Defying Logic at Work and at Home (New York: Harper Colins, 2010), 27.

50 M. Saim Yeprem, İrade Hürriyeti ve İmam Mâtürîdî (Ankara: Türkiye Diyanet Vakfı Yayınları, 2016 ), 89.

51 Danko Georgiev, “A Linkage of Mind and Brain: Sir John Eccles and Modern Dualistic Interactionism”, Biomedical Reviews 22 (2011), 81-84.

52 Penrose, Kralin Yeni Aklı, 414.

53 Fred Alan Wolf, Kuantum Bilmecesi, çev. Mihriban Doğan (İstanbul: Omega Yayınları, 2016), 67. 
İllüzyon olsun ya da olmasın, bilinçli irade kişinin eylem için kendi ahlaki sorumluluğuna rehberlik eder. Bir hareket irade edildiğinde, öznenin hareket üzerindeki öznel hissi zihinde kendiliğinden vücut bulur. İnsan, davranış kötü ise suçlu; iyi ise değerli hisseder. Bu anlamda bilinçli iradenin işlevi bir pusula olmaktır. Özgür irade kişiye "an"1 fark etmeyi, bedenin hem içinden hem dışından gözlemlemeyi sağlar ve icra edilen eylemlerin aksiyolojik durumuna uygun duygular hissedilmesine kılavuzluk eder. Bilinçli deneyimler, ahlaki yaşamlar üzerinde davranışların nedensel gerçekliğinden çok daha fazla etkiye sahip olabilir. İmam Mâtürîdî’nin asırlar evvelinden belirttiği gibi irade hürriyeti hakkındaki asıl bilgi daha çok sezgisel görünmektedir. "Gerçek şu ki, her birimiz bilinçli iradeye sahipmişiz gibi görünüyor. Görünüşe göre ona sahibiz. Zihnimiz var gibi görünüyor. Görünüşe göre özneyiz. Görünüşe göre yaptığımızın nedeniyiz." ${ }^{54}$

İnsan, iradesini kullanarak istediğini seçme hususunda yeterli ve kesin bir ilk nedene sahip olmamakla itham edildiğinde şöyle deme seçeneğine sahiptir: "Belki de öyle. Ama bu, seçmediğim anlamına gelmiyor. ${ }^{55}$ Kişi, istediğini seçmek için önceden yeterli ve kesin sebeplerden yoksunsa bunun nedeni; özgür olmaması değil, kişisel şartlarının hazır bulunuşluk sürecinin tamamlanmamışlı̆̆ıdır. Belki bu yüzdendir ki karar verirken, tercihte bulunurken tüm duyusal, duygusal ve rasyonel yeteneğini işe koşar ve sonra da neticesinden asla emin olamayacağı için bekler, belki tevekkül eder. "Romanın yazarı gibi, ben de bir öykü yazma ve bir insan oluşturma sürecindeyim ki o, hikayemdeki/olayımdaki kendimdir. Bu ağır bir yük, ama kesinlikle insani. ${ }^{.56}$ Özgür olmak, kendi serencamında aktör olmaktır. Bu aktörlük, failin güç yetirebilme kabiliyeti (potansiyeli) ile ilgilidir ki bu kuvve ile fert, dilediğinde nedensellik zincirini kırabilmeyi başarır.

Determinizm ve özgürlük arasında bir seçim yapmak zorunda kalmak "ya özgürlük ya belirleyicilik" şeklindeki dikotomik yaklaşımı haklı çıkarmaz. Haddizatında özgürlük adı verilen şey, tek başına adı özgür irade olan bir elektrik düğmesinden ibaret değildir. ${ }^{57}$ Özgürlük, bir potansiyeldir ve sürekli olarak niyetlilikle yol alan, inşa edilen bir olgudur. Dışarıdaki hayatın gerçeklerine karşı savaşmaktan ziyade onlarla barışık yaşamanın yollarını bulmaktır.

Nörobilimin bulgularının irade özgürlüğünün aleyhine kullanılmasında, bilimsel epistemolojinin kendi kısıtlılıkları dışında bazı yanlış değerlendirmeler yatmaktadır:

Birincisi, özgürlük kavramının sağduyulu kabulü, sinir bilimsel gelişmelerden bağımsız olarak vakidir. İkincisi, genel olarak modern bilimin epistemolojik sorunları nedeniyle sinir bilim, sezgisel gerçeklikleri ortadan kaldıracak kudreti haiz değildir. Üçüncüsü, yapılan son araştırmalar, insanlar sinir bilimsel sonuçları özgürlüğün aleyhine olacak şekilde yorumlasa bile ahlaki sorumluluğa dayalı kararların büyük ölçüde etkilenmeyeceğini göstermektedir. ${ }^{58}$ Her ne kadar nörobilimdeki yeni bulgular, özgürlükle ile ilgili yeni tartışmalara kapı aralamaya devam

$54 \quad$ Daniel M. Wegner, The Illlusion of Concious Will (Cambridge: Massachusetts Institute of Technology, 2002), 341-342.

55 Kane, "Responsibility, Luck, and Chance: Reflections on Free Will and Indeterminism”, The Journal of Philosophy 96/5 (May, 1999), 217-240.

56 Kane, "Responsibility, Luck, and Chance: Reflections on Free Will and Indeterminism”, 217-240.

57 May, Kendini Arayan İnsan, 152-153.

58 Roskies, "Neuroscientific Challenges to Free Will and Responsibility", 419-423. 
etse de nöroetik endişeler, çoğu zaman kısmi bulguların yanlış yorumlanmasından kaynaklanmaktadır.

İnsan organizması bir kuantum mekanik sistemi gibi işliyor olabilir. Kesin olarak ölçülmüş ya da belirlenmiş herhangi bir gözlenebilir özellik yoktur. İnsanın doğası ile ilgili her soru cevabını bulmamışken onu mekanik doğanın fizik gibi belirli bir bilime indirgenmiş kavramlarıyla anlamaya çalışmak yanlıştır. Üstelik bildiğimiz bir şey varsa o da bilimsel araştırmanın sınırlarına erişmediğgimizdir. Bilimsel bilgi yöntemi itibariyle bize asla insan olmanın nasıl bir şey olduğu veya birinin bir şeyi neden yaptı̆̆ı (eylemin doğası) hakkında tam bir açıklama verebilecek nitelikte değildir. İnsan bedeninin çalışmasını, özellikle beyin ve zihnin mekanik modellerini üretmek için araştırma yapmak makuldür. Sadece ne herhangi bir mekanik model insanı açıklamada tümüyle uygundur ne de sadece fiziksel terimlere dayanan bir açıklama. Modeller ve açıklamalar yaldızlı harflerle süslenmeye devam edecek fakat daha öteye gidemeyecektir. Geride söylenecek bir söz her zaman kalacak ve "puzzle"ın eksik parçası gibi teoride tamamlanmamışlık hissi yakînî olarak hissedilecektir. Çünkü bilimsel bilgi sürekli değişecek, yenilenecek ve önceki söylediklerinin eksikliklerini fark ederek insana dair bilgisini biraz daha öteye götürecektir. İnsan bir su ya da toprak gibi sadece maddeden ibaret değildir. Haddizatında maddi yapılar hakkında bile bilgiler itmam olmuş değildir. ${ }^{59}$ Bilimsel araştırmaya keyfi bir sınır çekilemeyeceği gibi hiçbir bilimsel çaba da insan zihninin sonsuz çeşitliliğini bitirebilecek kudrette görünmemektedir.

İnsan derin bir özgürlük inancına sahiptir. Özgür olduğunu bilir. Bilimsel bir görüşe göre insan kendisi hakkında düşündüğünden beri sınırlı bir özgürlüğün müdrikidir fakat bunun mahiyetine vakıf değildir. Ne tamamen özgür ne de tamamen belirlenmiş ve zapturapt altına alınmış bir varlıktır. Doğanın evrensel kurallarına ve her şeyin sebep-sonuç bağlamında açılanabileceği iddiasına bir istisna olarak insan özgür hisseder. İnsanoğlu farklıdır ve gizemli bir şekilde doğa yasalarının yönetiminden muaftır. Özgürlük insan tekinin içinde örülüdür. En temel düzeyde hayat, akıntılardan bize düşen paylarla doludur ve her türlü belirlenimciliği reddeden bir esnekliğe sahiptir. ${ }^{60}$

Özgür irade doktrinini sürdürmek için sadece antropomorfik gericiliğin kaldığını ileri sürenler ${ }^{61}$ bile özgürlükten vazgeçmede mütereddittir. Zira son elli yıl içinde sinir bilimin hayranlık uyandıran yükselişine rağmen insanın sadece biyolojik bir varlık olarak tanımlanmasının olanaksızlığ1 gözler önüne serilmiştir. İndirgemeciliğin esas ve usulleri, sürekli yinelenen handikap ve çıkmazlar olarak insanı anlamanın önündeki en büyük engellerden biri gibi görünmektedir. Nörobiyolojik yöntem ve terimlerle konunun vuzuha kavuşmayacağı, daha disiplinler arası ve bütüncül okumalara ihtiyaç duyulduğu fark edilmiştir.

Özgür olmadığımız doktrini -ki bu durumda organik bir makineyiz- günlük deneyimlerin bildirimlerinin ikame ettiği ve inkâr edilemeyecek şekilde kanıtlama gücünü haiz argümanların doğruladığı özgürlük hissine muhalefet eder. Özgürlük inancından vazgeçmek, ahlak ve rasyonalite başta olmak üzere kendimiz hakkındaki başka görüşlerden de vazgeçmek anlamına

\footnotetext{
59 Lucas, The Freedom of the Will, 167-168.

60 Jonah Lehrer, Proust Bir Sinirbilimciydi, çev. Ferit Burak Aydar (İstanbul: Boğaziçi Üniversitesi Yayınları, 2009), 58.

61 Lucas, The Freedom of the Will, 1.
} 
gelecektir. Belki de bütün bunların dışında insan olmak, özel ve diğer yaratılmışlardan farklı bir şekilde var olmaya tekabül etmektedir.

\section{Sonuç}

Hürriyet ve determinizm arasındaki ilişkiyi doğru bir şekilde tespit edebilmek için varlıkların ve kavramların hepsini bir sepete toplamadan analitik bir yaklaşım sergilemek gerekir. Maddi ile maneviyi, keyfiyetle kemiyeti, zaman ve mekân karşısında edilgen ile etkeni ayrı ayrı değerlendirmek esastır. Analitik yaklaşım sonucunda evrenin tartışmalı bir şekilde ve maddi boyutuyla determinizme mecbur olduğu ne kadar ileri sürülürse insanın da tartışmasız bir şekilde özgürlüğe mahkûm olduğu o kadar kabul edilecektir.

Eğer insan, şu an bulunduğu hâle programlanmış bir şekilde kendi iradi seçimleri olmaksızın gelmişse, benliğini belirleyen nitelikleri özgür yönelimlerle değiştirebilmesi hiçbir zaman mümkün değildir. Örgün ve yaygın eğitim başta olmak üzere doğruyu arayıp bulma, herhangi bir şekilde farklı davranma gibi bilinçli çabaların kıymeti harbiyesi olmayacaktır zira her şey bir şekilde geçmiş ya da an tarafından belirlenmiştir.

Diğer yandan bir eylemin özgür iradeye dayalı olarak gerçekleşmesi için sebepsiz/illetsiz meydana gelmesi şart değildir. Zira tek başına, eylemin bir nedenle vücut bulması iradeyi ortadan kaldırmayacaktır. Özgür irade yönetiminde icra edilen fiiller, içsel ve dışsal muhtelif tesirlerin etkisiyle gerçekleşebilirler. Ancak sebepler, iradeyi ortadan kaldırıp sonucu zorunlu bir şekilde intaç ettiğinde bir determinizmden bahsedilebilir. Zira özgür irade doğası gereği seçme anında zorunluluklardan berî olmalıdır. Fakat bir fiilin gerçekleşme süreci gerek afaki gerekse enfüsi şartların tetiklemesiyle başlamış olsa da bilinç ve iradenin oynadığı rol sayesinde sebepler bertaraf edilip fiil, yani sonuç oluşmayabilir yahut fiilin mahiyeti ve formu değiştirilebilir. İradenin görevi de zaten budur.

Her gün yeme içme alışkanlığına sahip bir insan, nafile oruca niyetlenip kendisini yeme içmeden alıkoyduğunda, devrede olan nitelik iradedir. Bu örnekte, kişinin günlük ve zorunlu yaşamsal faaliyeti sayılan yeme içmeden vaz geçmesinin sebebi, oruca niyetlenmiş olmasıdır. Oruca niyet etmesinin nedeni dinî duygudur. Bu dinî duygu; onun aldığı eğitim, yetiştiği çevre, ebeveyn etkisi vb. nedenlerle edinilmiş bir inanç olabilir. Baktığımızda insanın karakterinin şekillenmesinde etkili olan çevresel etkilere uzanan bir zincirleme reaksiyonla karşı karşıya olduğumuzu fark ederiz. Fakat o gün o saatte, kişinin nafile bir oruca niyetlenmesinin kararı, herhangi bir harici etki değil; bizzat kendi hür iradesidir.

Kişiliğimizin bir parçası olan bilişsel kodların teşekkülünde pek çok etken bulunur. Bu etkenler çoğu zaman ezber bilgiler yaratır ve otomatik/mekanik süreçler üretebilir. Nihayetinde insanoğlunun hayatı boyunca ortaya koyduğu davranışların pek çoğu bir otomatizm çerçevesinde cereyan eder. Fakat yukarıdaki örnekten anlaşılacağı üzere bir iyilik yapmaya ya da yapmamaya yahut nedensellik zinciri çerçevesinde önümüze gelen bir kötülüğü yapmaya ya da terk etmeye biz karar veririz. Bizi, diğer canlıların sağ kalım motivasyonları ve bedensel arzularına göre hareket etmelerinden ayıran temel özellik budur. Bu bilinçli farkındalık ve özgür irade, hayvanı insandan ayıran nihai niteliktir. Akıl ve düşünce gibi diğer hasletler ise bu sürecin hayati araçlarıdır. 
Peki, makro âlemdeki nedensellik ya da tartışmalı determinizm ile mikro âlemdeki indeterminizmi nasıl telif etmek gerekir? Anlaşılan o ki zorunlu ve zorunsuz parçalarıyla evren bir bütündür. Yani zitlar arasında bir birlikten (tevhitten), zıt niteliklerin bir araya getirdiği bir oluştan bahsetmek mümkündür. Şayet nedensellik olmasaydı evrenin bir matematiği ve belirli bir sisteminden söz edilemeyecekti. Oysa bu sistem sayesindedir ki insan ve diğer canlılar varoluşsal sürekliliğini sağlayabilmektedir. İnsanın içinde yaşadığı tabiatı ve kâinatı keşfedebilmesi için nedensellik ilkesi kritik önemi haizdir. Zorunsuzluk prensibi ise insanın özgür iradesini hem etkin kılabilmesi hem de felsefi planda temellendirmesi için elzemdir. 


\section{Kaynakça}

Ariely, Dan. The Upside of Irrationality: The Unexpected Benefits of Defying Logic at Work and at Home. New York: Harper Colins, 3. Basım, 2010.

Aydın, Mehmet S. Din Felsefesi. İzmir: İlahiyat Fakültesi Vakfı Yayınları, 7. Basım, 1999.

Baumeister, Roy F. The Cultural Animal: Human Nature, Meaning, and Social Life. New York: Oxford University Press, 2005.

Berofsky, Bernard. Nature's Challenge to Free Will. New York: Oxford University Press, 2012.

Bilmen, Ömer Nasuhi. Muvazzah İlm-i Kelâm. İstanbul: Ravza Yayınları, 3. Basım, 1959.

Block, Ned. Bilinç Üzerine Konuşmalar. haz. Susan Blackmore. çev. Seda Akbıyık. İstanbul: Küre Yayınları, 1. Basım, 2017.

Bolay, Süleyman Hayri. Felsefi Doktrinler Sözlüğ̈̈. Ankara: Akçağ Yayınları, 1990.

Caponigro, Michele. "Free Will from Outside Spacetime? The Role of Observer in Quantum Mechanics”. NeuroQuantology 16/8 (2018), 16-21. http://dx.doi.org/10.14704/nq.2018.16.8.1374

Damasio, Antonio R. Descartes'in Yanılgısı-Duygu, Akıl ve İnsan Beyni. çev. Bahar Atlamaz. İstanbul: Varlık Yayınları, 2. Basım, 999.

De La Mattrie, Julian Ofray. L'Homme Machine. çev. Ehra Bayramoğlu. İstanbul: Havass Yayınları, 1980.

Dennett, Daniel C. Özgürlüğün Evrimi. çev. Çağatay Tarhan. İstanbul: Alfa Yayıncılık, 1. Basım, 2016.

Ellis, George. How Can Physics Underlie the Mind, Top-Dawn Causation in the Human Context. Heidelberg: Springer-Verlag, 2016.

Erkol, Ahmet. “İslam Düşüncesinde Bir Okuma Örneği Olarak Cehm b. Safvan'ın Cebri Olduğu İddiasına Farklı Bir Yaklaşım”. Ekev Akademi Dergisi 7/17 (2003), 77-94.

Georgiev, Danko. "A Linkage of Mind and Brain: Sir John Eccles and Modern Dualistic İnteractionism”. Biomedical Reviews 22 (2011), 81-84.

Gould, Stephen Jay. Ever Since Darwin, Reflections in Natural History. New York: W. W. Norton \& Company, 2007.

Graves Jr., Joseph L. "Great Is Their Sin: Biological Determinism in the Age of Genomics". Annals of AAPSS 661 (September 2015), 24-50. https://doi.org/10.1177\%2F0002716215586558

Griffin, David Ray. Religion and Scientific Naturalism, Overcoming to Conflicts. New York: State University of New York Press, 2000.

Güler, İlhami. Allah'in Ahlakiliği Sorunu. Ankara: Ankara Okulu Yayınları, 1. Basım, 1998.

Herrnstein, Richard. “I.Q.”. The Atlantic 228 (1971), 43-64.

Hodgson, David. The Oxford Handbook of Free Will. ed. Robert Kane. New York: Oxford University Press, 2. Basım, 2002. 
Hook, Sidney. The Quest for Being and Other Studies in Naturalism and Humanism. London: Macmillan, 1961.

Inwagen, Peter von. "The Incompatibility of Responsability And Determinism". Action and Responsibility. Ed. Michael Bradie-Myles Brand. 30-37. Ohio: Bowling Green State University, 1980. İzutsu, Toshihiko. Kuran'da Allah ve İnsan. çev. Süleyman Ateş. İstanbul: Yeni Ufuklar Neşriyat, ts. Jensen, Arthur R. "Intelligence, Learning Ability and Socioeconomic Status". The Journal of Special Education 3/23 (1969), 23-35. https://doi.org/10.1177/002246696900300103

Jensen, Arthur R. "How Much Can We Boost IQ and Scholastic Achievement", Harvard Educational Review 39/1 (1969), 1-123. https://doi.org/10.17763/haer.39.1.13u15956627424k7

Johnson Fred W. - Jensen, Arthur R. "Race and Sex Differences in Head Size and IQ". İntelligence 18 (1994), 309-333. https://doi.org/10.1016/0160-2896(94)90032-9

Kane, Robert. The Significance of Free Will. New York: Oxford University Press, 1998.

Kane, Robert. "Responsibility, Luck, and Chance: Reflections on Free Will and Indeterminism". The Journal of Philosophy 96/5 (May, 1999), 217-240. https://doi.org/10.2307/2564666

Kutsal Kitap ve Deuterokanonik Kitaplar. İstanbul: Kitabı Mukaddes Şirketi, 2015.

Lehrer, Jonah. Proust Bir Sinirbilimciydi. çev. Ferit Burak Aydar. İstanbul: Boğaziçi Üniversitesi Yayınları, 2009.

Libet, Benjamin. “Do We Have Free Will?”. Journal of Consciousness Studies 6 (1999), 47-57.

Lucas, John Randolph. The Freedom of the Will. Oxford: Clarendon Press, 1970.

Malabou, Catherine. Beynimizle Ne Yapmalyıı. çev. Selim Karlıtekin. İstanbul: Küre Yayınları, 1. Basim, 2010.

May, Rollo. Kendini Arayan İnsan. çev. Ayşen Karpat. İstanbul: Kuraldışı Yayıncılık, 1997.

Mill, John Stuart. A System of Logic Ratiocinative and İnductive. Books IV-VI. ed. J.M. Robson. USA: Harper \& Brothers, 8. Basım, 1981.

Miller, William R. - Atencio, David J. "Free Will as a Proportion of Variance". Are We Free? Psychology and Free Will. ed. John Baer vd. 275-295. New York: Oxford University Press, 2008.

Myers, David G. "Determined and Free", Are We Free? Psychology and Free Will. ed. John Baer. 32-43. New York: Oxford University Press, 2008.

Neslioğlu, Funda. “İrade Özgürlüğü Sorununun Çözümsüzlüğü Üzerine”, Felsefe Dünyası 47 (2008/1), 179-184.

Nichols, Shaun. "Folk İntuitions on Free Will". Journal of Cognition and Culture 6 (2006), 57-86. https://doi.org/10.1163/156853706776931385

Nichols, Shaun. "The Folk Psychology of Free Will: Fits and Starts". Mind and Language 19 (2004), 473-502. https://psycnet.apa.org/doi/10.1111/j.0268-1064.2004.00269.x

Öktem, M. Niyazi. Özgürlük Sorunu ve Hukuk. İstanbul: iÜ Hukuk Fakültesi Yayınları, 1977. 
Penrose, Roger. Kralın Yeni Aklı-Bilgisayar, Zekâ ve Fizik Yasaları. çev. Tekin Dereli. İstanbul: Koç Üniversitesi Yayınları, 2. Basım, 2017.

Pinker, Steven. "The Fear of Determinism”. Are We Free? Psychology and Free Will. ed. John Baer vd. 311-324. New York: Oxford University Press, 2008.

Popper, Karl - Eccles, John J. The Self and Its Brain - An Argument for Interactionism. New York: Springer İnternational, 1983.

Rodd, Rosemary. "The Challenge of Biological Determinism". Philosophy 62/239 (1987), 84-93. https://doi.org/10.1017/s0031819100038614

Roskies, Adina L. “Why Libet's Studies Don't Pose a Threat to Free Will In Conscious Will and Responsibility". Conscious Will and Responsibility: A Tribute to Benjamin Libet (Oxford Series in Neuroscience, Law and Philosophy). ed. W. Sinnott vd. New York: Oxford University Press, 2011.

Roskies, Adina. "Neuroscientific Challenges to Free Will and Responsibility". TRENDS in Cognitive Sciences 10/9 (2006), 419-423. https://doi.org/10.1016/j.tics.2006.07.011

Tiger, Lionel - Fox, Robin. The Imperial Man. New York: Routledge, 1971.

Tiger, Lionel - Fox, Robin. “The Zoological Perspective in Social Science”. Man 1/1 (1966), 75-81. https://doi.org/10.2307/2795902

Wegner, Daniel M. The illusion of Concious Will. Cambridge: Massachusetts Institute of Technology, 2002.

Weber, Shannon. "What's Wrong with Be(com)ing Queer? Biological Determinism as Discursive Queer Hegemony”. Sexualities 15/5/6 679-701. https://doi.org/10.1177\%2F1363460712446275

Wolf, Fred Alan. Kuantum Bilmecesi. çev. Mihriban Doğan. İstanbul: Omega Yayınları, 3. Basım, 2016. Yeprem, M. Saim. İrade Hürriyeti ve İmam Mâtürîdî. Ankara: Diyanet Vakfı Yayınları, 1. Basım, 2016. 